\title{
Letting Scotus Speak for Himself
}

\section{MARY BETH INGHAM}

\section{Loyola Marymount University}

In "The Unmitigated Scotus," Thomas Williams calls for another, better reading of the Subtle Doctor: one in which he is able to "speak for himself."1 In this and other articles, Williams criticizes recent Scotist scholarship for its misguided attempt to save Scotus from "the unpalatable position" he actually held, that is, a libertarian voluntarist divine command moral philosophy. ${ }^{2} \mathrm{He}$ presents his position as one that, finally, allows Scotus to speak for himself.

Williams's position involves three distinct claims. First, that Scotus's voluntarism is not moderate. Second, that he defends a libertarian notion of freedom, both in the divine and human wills. Third, that, as a result of the first two claims, natural reason is unable to know moral truths without some sort of supernatural revelation or immediate moral intuition. While these are clearly related, they must be argued for independently of one another. For example, Scotus could be a moderate voluntarist about the human will and a libertarian about the divine will. Additionally, he might be both a moderate voluntarist and nonlibertarian who defends some sort of supernatural requirement for moral judgment. So, even if the radical voluntarist, libertarian divine command claim in its most extreme form is unwarranted, one might defend it in a more nuanced formulation.

In this article, I examine these three claims against a context that is both historical and textual. I agree that scholars must seek what is most central and distinctive about Scotist thought. This goal, I would argue, is better accomplished when Scotus's voluntarism is seen as part of the thirteenthcentury debate between philosophers and theologians. Likewise, the claim about a libertarian notion of freedom in the divine will must be tested against numerous texts, specifically those that present a more theological discussion. The consequences for a libertarian notion of freedom in the human will bear similar scrutiny on the basis of several texts where Scotus outlines the metaphysical requirements for the rational will. The question of a need for revelation is best understood on the basis of these prior questions.

1. Archiv für Geschichte der Philosophie 80. Bd, 1998, p. 162.

2. Thomas Williams, "How Scotus Separates Morality from Happiness," American Catholic Philosophical Quarterly 69 (1995): 425-46; Williams, "Reason, Morality, and Voluntarism in Duns Scotus: A Pseudo-Problem Dissolved," The Modern Schoolman, 74 (1997): 73-94; Williams, "The Libertarian Foundations of Scotus's Moral Philosophy,” The Thomist 62 (1998): 193-215. 
In what follows, I present, first, what I understand to be central to Williams's interpretation. Following this, I take up separately the claims about voluntarism and libertarian freedom in Scotus. A more complete definition of Scotus's voluntarism is needed to demonstrate that it is, indeed, moderate. This involves both historical and textual data. When it comes to the libertarian claim, I consider the divine will as it appears both in Ordinatio IV, 46 (the discussion of divine justice) and Ordinatio I, 17 (the discussion of divine acceptatio and the order of merit). This textual analysis helps bring to light the exact nature of divine freedom Scotus defends. A similar look at Ordinatio II, 6 and Quaestiones Super Libros Metaphysicorum Aristotelis IX, 15 supports my claim about freedom and the rational human will. In the final section, I trace in broad strokes the implications for natural reason and the moral order.

Central to what follows is the claim about a libertarian notion of freedom and to what extent it is present in Scotist texts. If, indeed, Scotus can be shown to defend such a notion of freedom, even if only for the divine will, then Williams has good reason to make the sort of claims he makes. As I hope to show, there is insufficient textual evidence to support his case for a libertarian Scotus. Consequently, my study demonstrates that, where Williams misreads Scotus, he is not taking into account the larger context (both historical and theological) within which the arguments are expressed. As a result, his textual data do not warrant the sort of conclusions he draws.

\section{WILLIAMS'S POSITION ON SCOTUS'S VOLUNTARISM}

The position Williams presents on Scotus's libertarian voluntarism is actually quite simple and straightforward. It appears to develop coherently from the initial definition offered, both in "The Unmitigated Scotus" and "Reason, Morality, and Voluntarism." This definition has two parts, one concerning what is good and the other concerning the nature of divine willing. The first part of the definition claims that,

Claim 1: According to voluntarism, whatever is good (whether natural or moral) is good precisely because it is willed by God. All good, then, depends radically upon the divine will.

As this claim is developed, the primary focus is upon moral goodness and the way the moral law is established entirely by God's will. It would appear, then, that voluntarism according to Williams has solely to do with the question of moral foundationalism. His arguments are more concerned with why the moral law is what it is and how human reason is able to act morally. 
In "Reason, Morality, and Voluntarism" this notion of voluntarism is contrasted with the Scotist claim:

Claim 2: That right reasoning is a necessary condition for the morally good act.

Despite the obvious contradiction of Claims 1 and 2, Williams states, they can be easily reconciled, once Scotus is understood to be the radical libertarian he is. In fact, Scotus can assert both that the moral good depends on the divine will and that human reason is essential to moral deliberation and choice, once we realize that some sort of revelation (either the Decalogue or a moral intuition) is part and parcel of the Subtle Doctor's authentic teaching.

An essential piece of Williams's argument, however, is still missing. It is the piece that explains why Claims 1 and 2 would be so obviously in contradiction in the first place. The critical point for this involves the second part of the definition of voluntarism that grounds Williams's libertarian interpretation. It is not simply that the moral law depends upon the divine will, it is also the case, he claims,

Claim 3: That the divine will is radically independent of any determinants, whether it be reasons, the divine intellect, the divine nature or any thing about the contingent realm (requirements of human nature, for example). ${ }^{3}$

This aspect of the divine will, best presented in "The Unmitigated Scotus," really does seem to complicate matters for Scotist scholars. Because the divine will has no reasons to act, there is no way human reason can understand why the moral law is the law, and therefore no reason foundational to the moral order that is accessible to natural reason, absent revelation (of at least some sort). According to Williams, scholars of recent years have struggled to mitigate Scotus's voluntarism in order to save reason. In this, they are misguided because there is no contradiction between the sort of radical libertarian voluntarism that Scotus adheres to and the role of reason in moral living, once one admits the existence either of moral intuitions or of the need for divine revelation.

The final piece of Williams's interpretation, then, involves the role of revelation and how human reason knows both what is good and why it is good. We thus have

3. "The goodness of almost all things, as well as the rightness of almost all acts, depends wholly on the divine will and that what God wills with respect to those things and those acts is not in turn to be explained by reference to the divine intellect, human nature or anything else" ("The Unmitigated Scotus," p. 162). "In short, no facts about human nature, divine nature, particular people, or particular situations constrain God's contingent and sovereign willing of the moral law" ("Reason, Morality, and Voluntarism," pp. 91-92). 
Claim 4: Some sort of revelation (Scripture) or immediate moral intuition is needed.

In "How Scotus Separates Morality from Happiness," Williams suggests that revelation in the Decalogue provides just this sort of moral information needed by the will in order to do what is right. Scripture offers that precise moral data needed by an individual in order to ground right choice. Without such information, the affection for justice (the will's moral affection) is empty and human moral judgment is impaired. ${ }^{4}$ In "Reason, Morality, and Voluntarism" and "The Unmitigated Scotus," Williams explains that natural reason can know the moral law, but only in an epistemically immediate manner. Such immediate moral intuition relates to the commands of the second table of the Decalogue (the contingent elements of moral law, according to Scotus) insofar as they are the law, "written on our hearts," as St. Paul claims.

If one accepts both parts of the definition of voluntarism that Williams presents (Claims 1 and 3) then there is a problem in reconciling human reason with freedom. Additionally, the conclusions he draws about revelation and intuition are needed to present a coherent Scotist teaching on the will. I do not accept the two claims, nor do I think they offer an authentic version of Scotus's position on the divine and human freedom. Nonetheless, like Williams, I see no problem reconciling human reason with freedom because, for Scotus, the will is rational. And, while I agree that, for Scotus, moral truth is grounded on the divine will, I do not think he argues for the need for divine revelation of moral law, nor do I find textual support for "moral intuitionism."

My critique of Williams's position, then, involves a modification of Claim 1 and a rejection of Claim 3. Claim 1 is a partial-thus inadequatedefinition because it relies only on the way moral law relates to the divine will. Voluntarism (especially medieval voluntarism) has a much broader definition, particularly in light of the historical developments of the thirteenth century. Claim 3 is simply misleading because, for Scotus, the divine nature is simple and the will is the sole rational potency. Therefore, any interpretation that either denies the will's access to reason or attempts to defend a notion of freedom that does not entail rationality cannot be faithful to Scotus. For him, the will (whether human or divine) enjoys a freedom that is undetermined by external factors precisely because it is rational. This means that the suggested contradiction between Claims 1 and 2 in "Reason, Morality, and Voluntarism" is exactly what Williams says, "a pseudo-problem." It

4. "The affectio iustitiae cannot of course tell us that God has commanded a particular moral law; it is not a cognitive faculty ... This inclination gives us a 'sense' of what is morally required of us, a sense utterly independent of the satisfaction of our desires or even the perfection of our nature as rational agents. In this way we have immediate, non-discursive awareness that certain actions are right or wrong" (Williams, "How Scotus Separates," p. 438). 
can be solved, not by introducing a layer for revelation or moral intuitionism, but by defining freedom as Scotus does, that is, in terms of rationality within the will. When, at last, it comes to Claim 4, while it is true that there is a dimension of Scotus's thought that involves divine command, this is limited to moral foundationalism. I present two texts to show that Scotus did not hold the need for scripture for moral judgment nor to the existence of immediate moral intuitions.

The weaknesses of Williams's argument for a libertarian Scotus are to be found in the premises, first about the narrow definition of voluntarism (Claim 1) and second, about the characterization of the divine will and its independence from the divine essence and reason (Claim 3). In light of the strong statements Williams makes about the authenticity of his own interpretation, these weaknesses are not simply insignificant aspects to be corrected. Rather, they contribute to a false depiction of Scotus insofar as they inform the way texts are chosen, removed from context and presented in evidence. It is a partial reading of Scotus that is to blame for this inaccurate presentation.

\section{THE CLAIM THAT SCOTUS IS A RADICAL VOLUNTARIST IS UNFOUNDED}

In "The Unmitigated Scotus," Williams seeks to present the voluntarism of the Subtle Doctor in the most authentic manner, that is, unmitigated in the way that so many scholars have tried to tone down what is so implausible and unacceptable in his teaching. Scotus's voluntarism is unacceptable if it is taken as the Franciscan intends it. "Interpreters who read Scotus as a voluntarist intend thereby to damn his moral views; interpreters sympathetic to his moral views feel compelled to mitigate his voluntarism. I wish to argue for a different approach." Scotus must be allowed to speak for himself, and to present his own radical and authentic voluntarism.

The clearest expression of this overall position appears in "Reason, Morality, and Voluntarism." There Williams introduces the Scotist problematic that so many recent scholars have, in his opinion, tried to avoid:

I have never seen the argument made, but it must go more or less as follows. Voluntarists hold that what is morally right depends on what God wills. So if we are to know right from wrong, we must know what God wills with respect to the moral law. Since, however, God's will is (according to voluntarism) not determined by any reasons, it would seem that human reason would be powerless to figure out what God wills with

5. Williams, "The Unmitigated Scotus," p. 162. 
respect to the moral law. After all, if there are no reasons God consults in order to decide what to will regarding the moral law, there are certainly no reasons we can consult. ${ }^{6}$

Whether or not anyone has ever tried to defend this claim, ${ }^{7}$ Scotus is a voluntarist, Williams maintains, and precisely in this radical libertarian form. ${ }^{8}$ The definition of voluntarism used here by Williams grounds his argument. It relates solely to the relationship between the divine will and the moral good. Because of the way the definition is focused on that relationship, it contains, at least implicitly, the need for some sort of divine command, revealed or inspired. That need is strengthened by the additional claim of voluntarism (Claim 3): that the divine will is undetermined by any reasons, nor can it be explained by anything else.

In this section I consider the first aspect of the definition of voluntarism (Claim 1): that voluntarism refers only to the position, stated above, that "the goodness of almost all things, as well as the rightness of almost all acts, depends wholly on the divine will." This means that voluntarism refers solely to the relationship of the moral law to the divine will. A voluntarist would then be a thinker who holds that the moral law depends radically upon the divine will. Since Williams claims he has here offered a precise and authentic definition of Scotus's voluntarism, one may reasonably ask if this definition is sufficient. It is not enough for this definition to be accepted by contemporary thinkers, or to be acknowledged today as an adequate or even preferred definition of voluntarism. It is not enough for this definition to answer questions of moral foundationalism. The definition must correspond to what Scotus himself understands by the term voluntarism. The criterion against which this definition should be measured must accord with the strong claims made by Williams himself: that this represents the true, authentic and genuine voluntarism of Scotus.

This definition fails to be an adequate depiction of Scotus's voluntarism, not because Scotus dismisses the divine will (which he does not), nor because he denies that moral goodness lies in a profound relationship to the divine will. On this, Williams's textual evidence is faultless. The definition fails because it is only a partial definition of Scotus's voluntarism. The foundation of the moral law on the divine will is only one aspect of a much larger vision, embraced by medieval voluntarists. To reduce voluntarism to the

6. Williams, "Reason, Morality, and Voluntarism," pp. 73-74.

7. As a matter of fact, I have never seen such an argument either. Even though he begins with this definition at the outset, Williams states (p. 86) that Scotus is not a "thoroughgoing voluntarist" in the sense that he denies the rational will. At this point, he appears to have joined the ranks of "moderate interpreters" whose position he disputes.

8. In "Reason, Morality, and Voluntarism," Williams claims that this is in fact Scotus's version of voluntarism. See p. 74 n.7. 
relationship between the divine will and the moral law ignores the nature of rational perfection Scotus defends, excludes morally relevant aspects such as the virtues, and deprives the natural order of any significant moral role. Additionally, such a narrow definition focuses any discussion of revelation to the Decalogue. If anything is revealed, it can only be the moral law, since that alone would be necessary.

Williams's definition of voluntarism fails, additionally, in that it offers no help to a scholar who seeks to distinguish the position of Scotus from that, for example, of William de la Mare, Peter John Olivi, or Henry of Ghent. This is particularly troublesome, given that Scotus goes to great efforts to critique Henry's voluntarism and to separate himself from the positions of the Ghentian master. An authentic definition would be helpful if it introduced a spectrum from conservative to moderate to radical. Accordingly, one could situate Scotus on such a continuum and understand how he developed his own position in light of others belonging to the same sort of tradition. Even if Scotus were the radical voluntarist Williams claims, then a better definition would help understand how he is more radical than thinker $\mathrm{X}$ or (if possible) less radical than thinker Y. In addition, such a definition could show why. If the only characteristic of voluntarism is that it refers to the dependency of the good on the divine will, then there can be no continuum or degree. Either a thinker holds that the good depends on the divine will or he does not. There appears to be no middle ground for partial-dependency on this point. In short, according to Williams's own definition, one can either be a voluntarist simpliciter or not.

At this point, the definition actually encounters textual problems. In Lectura II, 25, Scotus attacks Henry of Ghent's view of the will and depicts it as "extreme." In contrast to Henry, he presents his own moderate or "middle" position. If Williams's definition were one that Scotus accepted as his own, then his rejection of Henry's position would make no sense. Both Henry and Scotus hold that the divine will is the ground for moral goodness. Thus, according to Williams, they would be voluntarists in exactly the same sense. However, in this passage, Scotus clearly sees a difference between his position as a voluntarist and Henry's position as a voluntarist. He accuses Henry of defending a "blind will." He sees himself as more moderate about the will than Henry. This must mean that there is more to Scotus's voluntarism than Williams's definition allows.

Finally, the definition fails because of its narrow focus, one that actually creates the problems that Williams is trying to solve. This is particularly true when it comes to reason and its role in choice and in moral decisions (the suggested contradiction between Claims 1 and 2 above). Williams seeks to free Scotus from misguided interpreters. Yet his very definition of

9. "Alia opinio-Gandavi-extrema est, quod sola voluntas est causa effective respectu actus volendi," Lectura II, 25 in I. Duns Scoti, Opera Omnia (Civitas Vaticana: Typis Vaticanis, 1993), n. $54(19,246)$. 
voluntarism in Claim 1 causes many of the difficulties for his own argument. In the passage cited above, Williams maintains, first, that a voluntarist holds that moral goodness depends upon the divine will. Next he claims that (according to voluntarism) there is no reason why the divine will wills one thing rather than another. Suddenly the voluntarist position becomes a libertarian position. This position grounds the libertarian argument in "The Libertarian Foundations" and is the main focus in "The Unmitigated Scotus." Libertarian voluntarism, understood in this way, is already at odds, within the premises themselves, with reason and rationality. The divine will creates on the basis of no reasons. ${ }^{10}$ The human will can resolve "competing considerations in favor of incompatible courses of action" only by an "act of the will by which I decide to regard certain considerations as having a claim on me."11 This interpretation, quite simply, identifies reason with the intellect and not with the will.

Williams's definition runs up against both historical and textual difficulties. In order to grasp precisely the nature of the voluntarism Scotus actually held, one must carefully consider the historical evidence of the rich and varied thirteenth-century tradition. One must also look to those texts where Scotus deals with the will and how it cooperates with the intellect in the act of volition. Finally, one cannot ignore the presence of significant moral factors other than the will, such as the virtues, and how they function within his moral perspective. When all these aspects are taken into consideration one discovers a moral theory that is far more integrated and encompasses much more than the relationship of good actions to the law or to the divine will.

\section{Historical Evidence Against Scotus's Radical Voluntarism}

For medieval thinkers, voluntarism refers to that perspective on human nature and action that places the will in a position superior to the intellect. The term itself only has meaning relative to its opposite "intellectualism," where the superiority was reversed. Concretely, this meant that a voluntarist held that love was superior to knowledge and that, in heaven, loving God will take precedence over knowing God. In the Franciscan tradition of the thirteenth century, voluntarism expressed itself as a

10. "So Scotus denies that there is any reason external to the divine will that causes or explains God's willing as he does with respect to the contingent part of the moral law. Some interpreters, in an attempt to escape this conclusion, appeal to passages in which Scotus speaks of God as willing ordinatissime or rationabilissime. But a close look at these passages will show that the concept of willing ordinately or reasonably in no way mitigates Scotus's voluntarism" (Williams, "The Unmitigated Scotus," p. 177).

11. Williams, "Libertarian Foundations," p. 213. 
preference for the affective over the intellectual in the question of human perfection. ${ }^{12}$

Scotus's voluntarism, indeed his moderate voluntarism, is best understood within this context of thirteenth-century Franciscan thought. In his discussion of freedom in God, Scotus develops the voluntarist Franciscan tradition that had begun in Alexander of Hales and was explored further in the works of Bonaventure and, following 1277, William de la Mare, Peter John Olivi, and Richard of Middleton. As the thirteenth century reflection on human perfection intensified in light of the Nicomachean Ethics, positions on the will's freedom (both divine and human) became the focus for debate. ${ }^{13}$ Since, as Williams himself notes, all voluntarists hold that moral goodness depends on the divine will, differences among voluntarists did not appear on this point. For the most part, differences emerged as to the role of the intellect (or the object of cognition) in the act of choice and to questions about the will's superiority in commanding lower powers.

William of Ware, for example, represents the most crystallized version of thirteenth-century ethical voluntarism. Five aspects characterize his position.

1) The will is superior to the intellect.

2) Beatitude, human perfection, consists in the activity of the will and not the intellect.

3) Freedom derives from the will and not rationality.

4) The will is free to act counter to the intellect.

5) The will, and not the intellect, commands the body and the powers of the soul. ${ }^{14}$

Scotus is a voluntarist in the sense that he accepts four out of the five aspects listed above. He holds, in Ordinatio IV, 49, that the will is superior to the intellect and that human perfection consists in the activity of the will and not the intellect. ${ }^{15} \mathrm{He}$ argues as well that the will does not follow the commands of the intellect necessarily. The will commands the body and powers of the soul. It is, however, the third aspect that mitigates Scotus's voluntarism. For him, like Richard of Middleton, freedom is related to rationality because the

12. See Bonnie Kent, Virtues in the Will: The Transformation of Ethics in the Late Thirteenth Century (Washington, DC: Catholic University of America Press, 1995), pp. 94-95.

13. In addition to Kent's study, Georg Wieland has dealt with this in his "Happiness the Perfection of Man," in The Cambridge History of Later Medieval Philosophy (Cambridge: Cambridge University Press, 1981), pp. 673-86; and Wieland, EthicaScientia Practica (Munster: Aschendorff, 1981).

14. Kent, Virtues in the Will, p. 96.

15. "Certum autem est quod imperans est nobilior potentia exequente, et per consequens voluntas nobilior est intellectu" (Ordinatio IV, 49 ex latere, n. 14 [Vivès 24, 262b]). 
will is the rational potency. ${ }^{16}$ Indeed, it is the will's rationality that grounds its freedom. Therefore, when Scotus states that the will is free to act counter to what the intellect decides, he is not affirming that the will's freedom lies in its independence from rationality. Scotus's particular version of voluntarism is not, then, libertarian in the sense that freedom is opposed to reason or to questions of rationality. On this point, Williams may have confused Scotus's teaching with that of other voluntarists such as William de la Mare.

In his discussion of volition, Scotus's earliest Lectura teaching in II, 25, affirms the cocausality of intellect and will in the act of volition. The significance of this moderate position can be appreciated in light of the more extreme voluntarism of someone such as Peter John Olivi. In his reaction to the intellectual claims of Aristotle's Ethics, Olivi holds that the will is "totally active" efficient cause of volition. In other words, the efficient causality of the will (its freedom) is independent either from the object or from the intellect. ${ }^{17}$ Scotus, by contrast, defends a more moderate position of partial cocausality where the will and the "object as known" both contribute to the act of willing as una causa totalis.

I hold a middle position, that as the will and object contribute to causing the act of willing, so that this is from the will and the object known as from an effective cause. Yet how can this be from the object? For the object has abstract being and an agent must be something concrete and in act. So, I say that the intellect actually understanding an object concurs effectively with the will in causing the act of willing; in short, understanding the object is natural while choosing or not choosing is free. In this consists free will whether in us or in the angels. ${ }^{18}$

This text presents an aspect that is significant for the discussion of the rational will. This aspect is "the object as known" and "as present" to the will. Without this, states Scotus, the will is blind. Together, the act of the intellect and the act of the will produce the act of willing.

How is one to understand the role of intellection here? Certainly an object can only be known by the intellect. This object is "present to the will"

16. This aspect will be treated more carefully and in greater depth in part 2 .

17. "Voluntas est totaliter activa respectu actuum suorum, ita quod penitus nihil recipit ab obiecto nec ab intellectu, sed ipsa est sufficiens principium effectivum actuum suorum" (Quaest. In II Sent. q. 58, resp. [Jansen ed., II, 410]) cited in Kent, Virtues in the Will, p. 135.

18. "Ideo teneo viam mediam, quod tam voluntas quam obiectum concurrunt ad causandum actum volendi, ita quod actus volendi est a voluntate et ab obiecto cognito ut a causa effectiva. Sed quomodo potest hoc esse de obiecto? Nam obiectum habet esse abstractum in intellectu et oportet agens esse hoc-aliquid et in actu. Ideo dico quod cum voluntate in ratione causae effectivae concurrit intellectus-actu intelligens obiectum-ad causandum actum volendi, ut sic breviter 'natura actu intelligens obiectum et libera' est causa velle et nolle; et in hoc consistit liberum arbitrium, sive in nobis sive in angelis" (Lectura II, 25, nn. 69-70 [19, 253]). 
and within the will's power to accept or reject. Thus, the act of the will does not take place in the absence of the object, but neither is it determined by the object. However, the fact that the object is present to the will suggests more than mere external influence. The object lies within the will's power to accept or reject. The will's freedom is not affected by the presence of the object. Yet, the object as known by intellection is a cause of the act of willing. As Scotus himself states, in the act of willing, natural and free causal orders concur.

Henry of Ghent had held that the object known by the intellect functioned as causa sine qua non, or necessary condition for any act of volition. Scotus rejects this position on the grounds that it would leave the will blind and not account for all that free will (liberium arbitrium) requires. ${ }^{19}$ According to Scotus, the object known by the intellect must play a more significant role than a necessary condition. ${ }^{20}$ To act freely, then, means to act with knowledge. In the act of free choice, there is a natural efficient cause (the object as known) and a free efficient cause (the will). Natural and free causes concur to produce a single act of volition.

According to this moderate position, the will and the "object as known" function in a causal manner similar to father and mother in the birth of a child, or pen and stylus in the act of writing. Scotus explains this as partial efficient cocausality, where each cause is independent from the other and where neither cause derives its causality from the other. The act of volition is a type of giving birth from the will, which is the superior cause. The act of intellection (the object as known) is a partial efficient cocause, inferior to the will, but nevertheless present and active in volition. ${ }^{21}$

As this applies to Scotus's voluntarism, one might understand the object here to be the object of cognition, grounding the act of the will insofar as it focuses choice. An item on a menu, for example, would focus choice in this way. The object known could also be a situation or state of affairs that framed choice, complete with all relevant aspects or matters for the will's attention. In the case of almsgiving, this would include not just the beggar or the alms, but any aspect of the situation that cognition could make available to volition in order for choice to be reasonable. Finally, it could refer to the results of deliberation, the dictamen of right reasoning or prudence. In this

19. "Sed hoc non potest esse nisi quia cum voluntate concurrit ad causandum actum volendi, aliter enim liberum arbitrium esset caecum (quia libere volens, in quantum libere volens est, esset caecus); et ideo liberum arbitrium non tantum includit voluntatem, sed etiam cognitionem" (Lectura II, 25, n. 78 [19, 255-56]).

20. "Praeterea, arguitur ultimo sic: "agere libere" est per cognitionem, unde volens libere, ex hoc quod libere vult, non est caecus; ex hoc igitur quod quis libere vult, sequitur quod vult illud cognoscendo, ita quod in libertate includitur cognitio; igitur obiectum cognitum sive cognitio obiecti non requiritur ad actum voluntatis ut illud "sine quo non" tantum, sed tamquam aliqua causa inclusa in libertate et potestate liberi arbitrii" (Lectura II, 25, n. 68 [19, 252]).

21. See Scotus's discussion at nn. 70 (253) and 73 (254). 
way, the object as known could be a moral statement or proposition such as "Be generous." In each case, the intellect functions in tandem with the will as partial cocause for volition. In a case involving rich and diverse information, the will can direct the intellect to consider something more carefully, or to focus attention on a minor rather than a major point. It can also turn the intellect away. At no time, however, is the will necessarily determined to act one way rather than another by the presence of the object as known. This is particularly the case where right reasoning (in the intellect) issues a moral proposition. And, while the will need not reject (nolle) the moral dictate, it can exercise its freedom in refraining from choice at this time (non velle).

In the Lectura, Scotus presents this solution of partial cocausality as moderate, rejecting both the extreme voluntarism of Henry of Ghent and the extreme intellectualism of Godfrey of Fontaines. In this way, he attempts to save free will from the blindness of Henry's position and the intellectual determinism of Godfrey. ${ }^{22}$ It is important to note that Scotus's understanding of the will as sole rational potency is key to the sort of voluntarist he is. Others, such as William de la Mare, Peter John Olivi, and Henry of Ghent, were more extreme in their affirmation of the will's freedom because they did not ground that freedom on the will's rationality. Both Henry and Olivi held the intellect to be the seat of rationality. Thus, when they contrast the act of the will with that of the intellect, they do separate freedom from reason. Scotus does not follow them on this point.

\section{Textual Evidence Against the Claim of Radical Voluntarism}

A second argument in favor of Scotus's moderate voluntarism comes from a closer examination of his texts. Scotus lived and taught in Paris following the Condemnation of $1277 .{ }^{23}$ This historical fact has implications for the way his overall discussion focuses on the divine will and upon the nature

22. Stephen Dumont has recently documented that the later Reportatio version of this question does appear to endorse another position on the will. See his "Did Scotus Change His Mind on the Will?" in After the Condemnation of 1277-Philosophy and Theology at The University of Paris in the Last Quarter of the Thirteenth Century, eds. Aertsen, Emery, and Speer (Berlin: Walter de Gruyter, 2001), pp. 719-94. This later teaching, if authentic, would reveal a Scotus who holds that the object as known only functions as causa sine qua non (necessary condition) for the act of volition and that the will is the only efficient cause of its own act. I argue that this text can be reconciled with his position on the rational will and therefore does not necessarily give evidence of a more voluntarist teaching in Paris. I deal with both Lectura and Reportatio versions of II, 25 in much greater detail in "Did Scotus Modify his Position on the Relationship of Intellect and Will?" Recherches de Théologie et Philosophie Médiévales 69, 1 (2002): 88-116.

23. The classic study on this remains Roland Hissette's Enquête sure les 219 articles condamnés à Paris le 7 mars 1277 (Louvain-Paris: Philosophes Médiévaux, 1977). 
of freedom. ${ }^{24}$ His own presentation of his thought against the background of the "controversy between philosophers and theologians" (in the Ordinatio Prologue) offers texual evidence that Scotus understood rational perfection differently than did the philosophers teaching in the Faculty of Arts.

The condemnation was a turning point for medieval speculation. This is not so much because it revealed error that was taught in Paris. Rather, even if no one held the positions it condemned, the listing of these 219 propositions offered a crystallized philosophical project that was a viable natural alternative to the life according to the Gospel. ${ }^{25}$ Several propositions on the list of 219 related directly to divine action and to God's inability to choose independently of natural conditions or necessary constraints. Proposition $20^{26}$ claims, Quod Deum necesse est facere quidquid immediate fit ab ipso. ${ }^{27}$ Scotus makes direct reference to this proposition as an example of faulty philosophical reasoning in absence of revelation. ${ }^{28}$ What the philosophers do not know has to do with the divine nature. Revelation is necessary because God is Trinity of persons who acts freely in human history. It is not necessary so that human reason can know the moral law.

SCOTUS'S POSITION ON HUMAN PERFECTION DOES NOT SUPPORT THE CLAIM OF RADICAL VOLUNTARISM

Scotus opens his Sentence Commentary with the problem of the necessity for divine revelation in this life. The question asks: Does man in his present state

24. See Fernand van Steenberghen, "La Philosophie à la veille de l'entrée en scène de Jean Duns Scot," in De Doctrina I. Duns Scoti (Rome: Societas Internationalis Scotistica, 1968), 1:65-74; Paul Vignaux, "Valeur morale et valeur de salut," in Homo et Mundus (Rome: Societas Internationalis Scotistica, 1984), pp. 53-67.

25. See Alain de Libera, Penser au Moyen Age (Paris: Editions du Seuil, 1991), esp. pp. 202-3.

26. Mandonnet's numbering.

27. "That God of necessity makes whatever comes immediately from him. This is erroneous whether we are speaking of the necessity of coercion, which destroys liberty, or of the necessity of immutability, which implies the inability to do otherwise." The text of this condemnation can be found in Denifle and Chatelain, Chartularium Universitatis Pariensiensis 1:543-58. Glorieux writes in "Tempier, Etienne" (in Dictionnaire de la Théologie Catholique XV, 1, 99) that Tempier's action "exerça pourtant une influence considérable sur le développement et l'orientation de la pensée philosophique et théologique au XIIIe s. par ses deux interventions da la polémique antiavérroiste et antipéripatétique: sa condamnation de 1270 et son Syllabus de 1277."

28. See the Ordinatio Prologue, Pars I, q. unica, n. 41: "Proprietas etiam istius naturae ad extra est contingenter causare; et ad oppositum huius magis effectus ducunt, in errorem, sicut patet per opinionem philosophorum, ponentium primum necessario causare quidquid causat" (I:24). I deal with the implications of the 1277 condemnation on Scotist thought more fully in "The Condemnation of 1277: Another Light on Scotist Ethics," Freiburger Zeitschrift für Philosophie und Theologie 37 (1990): 91-103. 
need to be supernaturally inspired with some knowledge ${ }^{29}$ The textual presentation centers on a debate, much like a medieval disputed question, for which Scotus himself serves as Master, offering the determination that brings the two parties together. He states, "about this question, there is a controversy between the philosophers and theologians." Scotus depicts the philosophers as defending a position that views the natural order as foundation for any sort of salvation or human fulfillment. Aristotle's works provide the basis for their cognitive optimism and support their conclusion that revelation is unnecessary for human salvation. In the text, Scotus contrasts their philosophical position to that of theologians. These latter both question the philosophical project as capable of leading to the goal they state and point to the unknowability of the divine will. For such theologians, knowledge of the goal is necessary for choice of the means leading to that goal. Since, in the absence of revelation, philosophers do not know what God chooses to reward with beatific vision, natural reason cannot provide them with any significant information about that human behavior which will result in the ultimate experience of happiness (defined by the theologians as the vision of God). They also suggest that, since Aristotle himself questions whether or not eudaimonia exists, then in the absence of revelation, philosophers are either in error or in doubt as to the rightness of their own position. ${ }^{30}$

When Scotus enters the disputation in order to determine the question, he brings together both the philosophers' and the theologians' positions to affirm the dignity of nature and divine freedom for self-revelation. He does this through a consideration of the definition of the term supernatural. While no act of human cognition ever violates the intellect's nature, not everything that exists can be naturally known by the human intellect. This is the case because not every object of the human mind is within the natural grasp of human intellection. The experience of the beatific vision, for example, both belongs naturally to human cognition and involves an object (the divine essence) that is an obiectum voluntarium, or freely revealed to the human mind. ${ }^{31}$ The same divine nature that is object of the beatific vision reveals itself in Scripture. Because philosophers fail to grasp the true

29. In I. Duns Scoti, Opera (Civitas Vaticana-Typis polyglottis Vaticanis, 1951), 1:1-58. I use the English translation from Allan B. Wolter, "Duns Scotus on the necessity of Revealed Knowledge," Franciscan Studies (1951): 265.

30. "Hence it is with some doubt in mind that he [Aristotle] says in the first book of the Ethics (chap. 9, 1099b 11-13): 'If there be any gift of the gods, it is reasonable that it be happiness." Ordinatio Prologue, n. 14 (I, 10) in "Duns Scotus on the Necessity," p. 245.

31. Paul Vignaux's work is essential on this point. See Vignaux, "Infini, liberté et histoire du salut," in Deus et homo ad mentem I. Duns Scoti (Rome: Societas Internationalis Scotistica, 1972), p. 498: "Dans l'annonce d'un salut de cette dimension objective, Dieu se révèle et la grâce de cette révélation est légitimement le point de départ d'un discours sur Dieu, d'une théologie spéculative." 
nature of the divine essence, they cannot understand the true nature of happiness as the activity that perfects and fulfills human rational nature. They erroneously conclude that the perfection of rationality is found in speculation.

The key to Scotus's response to the philosophers lies in the insight that rational perfection is not merely a personal intellectual achievement. It is a gift, the result of a relationship initiated by divine freedom and recorded in Scripture. The gift does not destroy natural dignity, rather it fulfills it. One implication of Scotus's determination is that intellectual excellence (understood as speculation) does not constitute the true perfection of the human person. Rather, it is love (understood as rational and ordered) that fulfills and perfects rational nature. This is the case because, as revelation makes clear, God's nature is rational, ordered, and generous love; furthermore, we are created in the image of God. The need for revelation, according to Scotus's voluntarist perspective, has less to do with the commands of the Decalogue, and more to do with the essence of God as loving Creator and generous Sustainer of all that exists. ${ }^{32}$

A better understanding of the contours of this debate, so briefly sketched here, can only help to enlighten scholars who seek to understand Scotus's texts. ${ }^{33}$ The Franciscan emphasizes the will's freedom both because it is the source of love and because the members of the Faculty of Arts of the preceding generation had (apparently) defended an intellectualist model of philosophical salvation as equal if not superior to following the Gospel. He does not side entirely with the theologians who represent a much more extreme position and would defend a stronger divine command position for moral living. It is important to the theologians' argument that the philosophers "do not know what God accepts as worthy of reward." "This is clearly a position more radical in its dependency on the divine will than the moderate solution proposed by Scotus. For him, revelation is necessary, not because it reveals the divine commands, but because it reveals the divine essence (deitas). This essence is the object of theology and does have significance for moral reflection. It is not the case, however, that moral reflection cannot take place in its absence.

With the recent excellent scholarly studies on the latter part of the thirteenth century, it would be imprudent to disregard the historical

32. According to Williams: "From all of this it follows that the affectio iustitiae can function only if we already recognize objects as commanded or forbidden; consequently, the operation of the affectio iustitiae cannot itself be the source of our knowledge of what is commanded or forbidden" ("How Scotus Separates," 439).

33. For a much more detailed study of the Prologue and how it reveals Scotus's position on human perfection, see my "Duns Scotus, Morality and Happiness: A Reply to Thomas Williams," American Catholic Philosophical Quarterly 74 (2000): 173-95.

34. Ordinatio Prologue, n. 18 (Vatican I:12-13). 
context within which Scotus developed his thought. ${ }^{35}$ He was not primarily responding to Thomas Aquinas, but as recent studies have shown, to Henry of Ghent. ${ }^{36}$ In addition, he saw his own project as part of a much broader discussion between philosophers and theologians in the first generation after the Condemnation of 1277. Among Franciscans, his voice was moderate.

\section{THE ROLE OF VIRTUE DOES NOT SUPPORT THE CLAIM OF RADICAL VOLUNTARISM}

In his presentation of the philosophers' position in the Ordinatio prologue, Scotus highlights their tendency toward a naturalism based upon Aristotle's intellectual optimism. It would seem that, in the eyes of the philosophers, human nature is capable of autonomous self-perfection. This perfection can be achieved through the virtues. According to this perspective, moral decisions become the logical result of intellectual insight; moral excellence the predictable consequence of training in virtue. In other words, to know and will the end is to will those means appropriate to that end.

Scotus centers his moral discussion on the will's capacity for selfdetermination. He frequently cites Augustine's maxim: "Nothing is so in the power of the will as the will itself." 37 Because this capacity in the will is foundational, the virtues never play a central role in his discussion, either of moral goodness (which is based upon free choice in the rational will) or upon the goal of moral living (which lies in choosing to do what is right for itself alone). For him, virtues are natural inclinations toward action that are themselves generated by acts of right choosing. They are not foundational because they are themselves the result of free choice in the will. Thus, they fall into the category of all that is "in the power of the will." Virtues do not define the morally good end; they themselves are generated by right choice and are thus the result of an already existing moral orientation within the

35. In addition to Bonnie Kent's Virtues in the Will, one can fruitfully consult A. Celano's "The finis hominis in the thirteenth-century commentaries on Aristotle's Nicomachean Ethics," AHDLMA 53 (1986): 23-53; as well as his "The End of Practical Wisdom: Ethics as a Science in the Thirteenth Century," Journal of the History of Philosophy 33 (1995): 225-43. Foundational to the problematic remains G. Wieland's Ethica-Scientia Practica: Die Angfänge der Philosophischen Ethik im 13. Jahrhundert, Münster: Aschendorff 1981. See also his "The Receptation and Interpretation of Aristotle's Ethics," The Cambridge History of Later Medieval Philosophy (Kretzmann, Kenny, Pinborg, eds.), Cambridge University Press (1982), 657-672.

36. Gordon A. Wilson provides a bibliography of the most recent work on this point. See "The Presence of Henry of Ghent in Scotus's Quaestiones Super Libros Metaphysicorum" in John Duns Scotus: Metaphysics and Ethics (Honnefelder, Wood, Dreyer, eds.), Brill (1996), 107-108.

37. Augustine, Retractions, I, 9 (8), n. 3 and 22 (21) n. 4, cited by Scotus in Quodlibet 16, n. 4. See God and Creatures: The Quodlibetal Questions (Alluntis/Wolter, eds.), Princeton University Press (1975), 373. 
will. Despite this fact, they are not morally insignificant. The absence of any mention of virtue in Williams's several articles on Scotus's voluntarism points to and is explained by the limitations imposed by his initial definition. Where the moral domain is framed by divine freedom, moral commands, and the human will, there is really no place for a discussion of virtue. Scotus not only discusses virtue, however, but he claims that the presence of virtue adds to the perfection of the moral act.

In Ordinatio III, suppl. Distinction 33, Scotus affirms that both the will and the intellect are capable of performing acts that are morally good and correct without the presence of any practical habit, moral or intellectual that one might identify as virtue. ${ }^{38}$ This discussion grounds the independence of both intellect and will on the fact that the practical habit must be generated by the faculty involved. Thus, right choosing in the will generates moral virtue, just as right judgment in the intellect generates prudence. The act of the will precedes the virtues and is the source for the development of all practical habits that thereafter assist the will in choosing rightly. This means that no virtue need exist for the will to choose as it ought. Virtue follows, and does not precede, right choice.

Scotus affirms the close link between virtuous dispositions and the will when he identifies "acting virtuously" with "acting with deliberation." ${ }^{39} \mathrm{He}$ maintains that no one acts virtuously by acting suddenly and without deliberation in the way that nature acts. As native to the will, virtue is natural insofar as the metaphysical constitution of the will explains how acts of deliberation and choice arise and leave an imprint upon human character. This trace of goodness left behind as a practical habit facilitates other deliberations and choices. But moral virtue can never be merely natural, since that would imply that human behavior is reducible to external factors, external to both the person and the operations of deliberation and choice. If virtue were to operate in this manner (and this is what I think Scotus would like to correct in the purely philosophical approach) then freedom would refer to the absence of impediments to the operation of natural desire. Behavioral training alone would be required for moral excellence. Chance would have a central role in any moral situation and sin would be reducible to errors of judgment.

The centrality of free choice for Scotus places all virtue, moral as well as theological, at an inferior order to the will. This appears clearly in Ordinatio I, Distinction 17, where he explains just how any habit, developed over time, influences the will. Scotus states clearly that no natural inclination nor practical habit can replace the importance of free choice central to moral action. However, this text also affirms clearly that the moral act is more perfect when performed in the presence of virtue and free choice in the

38. See Allan B. Wolter, Duns Scotus on the Will and Morality, Washington: Catholic University Press (1987), 333.

39. Wolter, Will and Morality, p. 345. 
will. ${ }^{40}$ In fact, a radical voluntarist position (one that affirms the complete independence of moral goodness from any natural, habitual influences) is considered and rejected by Scotus in favor of the more nuanced, moderate discussion of virtue and its role in moral goodness. ${ }^{41} \mathrm{He}$ prefers the solution that, in his words, "attributes more to the habit." ${ }^{2}$ While the will is perfectly capable of performing a morally good act in the absence of virtue, such an act would not be as perfect as one performed with virtue. ${ }^{43}$ Indeed, when both the will and virtue are present, both free and natural causes work to bring out the most perfect moral act. The act is the single result of two causal orders, operating in tandem. Here again is the explanation based upon partial cocausality, where natural and free causes cooperate in moral perfection, just as the object as known and the will cooperated in the act of volition.

On the basis of historical and textual evidence, Scotus's voluntarism is moderate. In his discussion of human perfection and the morally good act, he seeks to integrate the activity of intellection with that of free choice. Likewise, in his discussion of moral goodness, he does not favor an approach that would exclude virtuous inclinations. Williams has framed his study of Scotus far too narrowly to be able to accommodate all these texts and the important historical backdrop of thirteenth-century voluntarism. His proposed definition of voluntarism is therefore unacceptable for an accurate understanding of Scotus because it excludes from moral consideration what Scotus includes (virtue) and because it identifies Scotus with a position he did not hold (that of Henry of Ghent).

\section{THE CASE FOR A RADICAL LIBERTARIAN SCOTUS CANNOT BE SUSTAINED}

The affirmation of moderate voluntarism in Scotus does not necessarily entail that Scotus has no libertarian notion of freedom. One can easily imagine Scotus defending a moderate voluntarism for the human will and

40. "[T]amen minus perfecte operatur sine habitu quam cum habitu (et hoc, posito aequali conatu ex parte potentiae), sicut quando duae causae concurrunt ad effectum unum, una sola non potest per se in ita perfectum effectum sicut ambae simul." Ordinatio I, 17, n. $40(\mathrm{~V}, 154)$. Here again, one can see the co-causality that was used to explain how the act of volition depends upon free choice and the object as known.

41. The "fifth solution" is presented by Scotus at nn. 64-66 (V, 165-69).

42. "Tenendo tertiam viam (quae videtur attribuere plus habitui)" (Ordinatio I, 17$, n. $69[\mathrm{~V}, 171])$.

43. I present a much fuller analysis of this text in "Ea quae sunt ad finemReflections on Virtue as Means to Moral Excellence in Scotist Thought," Franciscan Studies 50 (1990): 177-95. 
a libertarian notion of freedom in the divine will. As I demonstrate in this section, however, the libertarian claim can only be successfully demonstrated by separating Scotus's theological insights about the divine essence from his discussion of the divine will, by showing that Scotus does not see the divine nature as simple, and by identifying reason (even in God) solely with the intellect and not the will. In other words, the case for a libertarian Scotus would have to present texts denying both that God's essence is expressed in harmony with God's actions and that God's will is rational. Since one cannot find such texts, and since Williams himself affirms what he would have to deny (that is, the rationality of the divine will), then the case for the libertarian Scotus cannot be sustained.

Although Williams's definition of voluntarism is foundational to his claim, the libertarian case he tries to make is the center of his argument. Claim 3, it will be remembered states,

Claim 3: That the divine will is radically independent of any determinants, whether it be reasons, the divine intellect, the divine nature or any thing about the contingent realm (requirements of human nature, for example).

In "The Unmitigated Scotus," this claim appears as "So Scotus denies that there is any reason external to the divine will that causes or explains God's willing as he does with respect to the contingent part of the moral law." 44 In "The Libertarian Foundations of Scotus's Moral Philosophy" Williams states,

Freedom thus conceived is a pure perfection, and like every other pure perfection it can, for Scotus, be predicated univocally of God and creatures. So for Scotus free creatures (that is, creatures who have wills) are free in exactly the same sense in which God is free. It is their likeness to God's unconditional creative activity that makes free actions valuable and noble. And for those free actions, as for God's, there can be no fully adequate explanation. ${ }^{45}$

Free actions, according to this libertarian discussion, have no external causes, nor can they be fully explained. Libertarian freedom refers not simply to the will as undetermined by external factors, but affirms that the exercise of freedom takes place in the presence of nothing other than itself. There are no reasons beyond divine freedom why God acts in a particular way. Not even the divine essence can be used to explain divine activity. Because of this radical freedom in God, there are no reasons that can explain the exercise of human freedom.

44. Williams, "The Unmitigated Scotus," p. 177.

45. Williams, "Libertarian Foundations," p. 210. 
Williams is clearly attempting to defend the will against any sort of determinism, but it is hard to see, despite his affirmations to the contrary, that this notion of freedom is not pure and spontaneous arbitrary behavior. Consider, for example, the affirmation that Scotus's notion of freedom is based upon synchronic rather than diachronic alternatives. This means that, at the moment of choice, the will is free to choose the contrary of what it chooses. This sort of freedom belongs to the will because it is undetermined by external influences.

It is possible to understand this Scotist affirmation in a nonlibertarian sense. Accordingly, the will is capable of such freedom because it lies within its own power; it moves itself to act. At the moment of choice, the will could act differently because it is capable of self-restraint. This is clearly this self-control that grounds moral responsibility and imputability. Because the will has dominion over itself, its free choice is defined only by what is internal to its own exercise. Therefore, nothing beyond the will is capable of determining or constraining the will. In light of the earlier discussion of the object as known and virtue, one can see that, in the free exercise of choice, both knowledge and virtue are within the power of the will, and do not compromise the will's freedom in any way. If one still wishes to call this a libertarian notion of freedom, it would only be in a technical sense. This could not be radical, because it accepts the way character influences the will's freedom. Character involves aspects of the person that Scotus places within the power of the will, and therefore, within that freedom of selfdetermination.

This is clearly not what Williams intends by his argument, nor by the term libertarian, as he uses it. For him, absolutely nothing influences or mitigates the will's independence, neither reasons nor essence. It is this radical sense of synchronic freedom that denies reason to the will and sets it free.

There is a better way that Williams could focus on the exercise of synchronic freedom, in order to defend a libertarian reading of Scotus. To do this, he would have to look not at why the will wills this or that, but rather why the will wills at all. In Scotist terminology, this means looking at the act of velle/non velle, not the act of velle/nolle. In "The Libertarian Foundations," however, Williams claims that this is precisely not the question at issue. ${ }^{46}$ It would not be a question taken seriously by someone who held that non velle is not an act at all but an absence of an act (it is not a velle). As the discussion of the human rational will demonstrates, however, Scotus

46. Williams treats the two acts of the will as undifferentiated on this point. See "Libertarian Foundations," pp. 195-96. Both the question "why does the will will?" and "why does the will will this or that?" are answered by Scotus in the same way: because it is the will. Williams concludes from this that the two acts are not distinct. I think they are distinct and that their distinction reveals the true nature of Scotus's position on freedom, in God or in the human will. 
holds that the non velle is indeed an act: it is an act of self-restraint within the will. This act reveals the will's relationship to itself and, ultimately, why, when all conditions are present, the will is free not to act. Yet if one were to focus on this internal act of the will, one would have to face the will and its identity as a person, complete with rationality and the character referred to above. Again, this could be used to defend a libertarian interpretation; however, I doubt that anyone deeply committed to libertarian freedom would want to accept character and virtue as part of the will's freedom.

In his presentation of libertarian freedom, Williams overlooks both the importance of this foundational velle/non velle freedom and the precise manner according to which divine freedom differs from human freedom. Free creatures are not free in exactly the same way God is free. God's freedom establishes the order of value as well as the order of created being; human freedom does not. In addition, in the act of divine choice, the two affections are one. This means that, for God, love for the highest good is always love for the self. As I show later, this represents the fullness of freedom and belongs to God by nature. It is the goal of human free choice.

One cannot, then, make the libertarian connection between the divine and human wills on the basis of the choice between "this or that" (in other words, the velle/nolle distinction). In his analysis, Williams only focuses on this act when he argues about the role of reasons and how they do not influence choice in the will. One could argue, however, for this sort of libertarian connection at the level of acting or not (velle/non velle), as both divine and human wills face choice from the perspective of self-movement. However, as mentioned above, this would introduce us into the internal constitution of the will and its relationship to itself and all that lies within its power: the object as known, the virtues, in short: its own character and identity. Any libertarian claim to be made from this sort of analysis would have to be moderate.

\section{Scotus's Presentation of the Divine Will Is Not Libertarian}

The case for the libertarian claim focuses on the divine will and is best presented in "The Unmitigated Scotus." In that article, Williams offers a two fold discussion of divine freedom. The first deals with the ontological order and the second with the moral order. He begins with the principle "Everything other than God is good because it is willed by God, and not vice versa." Williams claims that this assertion is extremely radical: namely, that whatever goodness or degree of goodness (whether essential or moral) any being has depends upon the act of divine willing that it have such goodness or degree of goodness. The ontological discussion concludes, "Here, at least, Scotus very clearly considers, and leaves open, the possibility that a creature's 
degree of essential goodness is determined by the divine will independently of the divine intellect." 47

I will begin with an examination of the ontological discussion. Consider, for example, the following Scotist passage cited by Williams:

Nor is this inequality [of essences] on account of some goodness presupposed in any objects other than himself [i.e., God], which is, as it were, the reason for his willing in this way or that. Rather, the reason is in the divine will. If it accepts those other things in a certain degree, they are good in that degree, not the other way around. Or if it be granted that some degree of essential goodness is shown in them as they are shown [to God's will] by his intellect in accordance with which they ought reasonably to please his will, one thing at any rate is certain: their pleasing him as far as [their being willed to have] actual existence is concerned is purely from the divine will apart from any other determining reason on their part. ${ }^{48}$

This passage affirms in a very clear manner what was stated above, namely that the entire created order derives its goodness from the divine will and, thus, from love. It states that the goodness of the created order results from, and is not itself the measure of, divine choice. It also locates reason within the divine will. In his commentary on this passage, Williams states: "Scotus here seems to toy with a very radical view indeed, suggesting that even the essential goodness of creatures is determined by the divine will." 49 At first glance, this view does not appear to be radical. After all, Aquinas himself affirms that the created order is the result of the divine creative act. Scotus has a profound commitment to the value of the created order and the dignity of nature as chosen and loved by God. The contingent nature of this world reveals divine love.

Scotus's statement does not, at least at first reading, appear to be radical. Fortunately, Williams elaborates on his understanding of this passage and draws out the implications he thinks are present. He states,

For example, given what angels and human beings are by their very natures, it is difficult to imagine how God could bring it about that angels do not have a greater degree of essential goodness than human beings. Unfortunately it is hard to know whether this essentialist intuition has any real claim on a philosopher who goes so far as to say that fire could be cold. Here at least, Scotus very clearly considers, and leaves open, the possibility that a creature's degree of essential goodness is determined by the divine will independently of the divine intellect. ${ }^{50}$

47. Williams, "The Unmitigated Scotus," pp. 166-67.

48. Ordinatio 3, d. 32, n. 6 (W: 7.2:693), cited in Williams, "The Unmitigated Scotus," p. 166.

49. Williams, "The Unmitigated Scotus," p. 166.

50. Williams, "The Unmitigated Scotus," pp. 166-67. 
There are several intellectual moves made in this short passage. We would do well to take them one at a time. The first suggests something about the created order of essences and their relationship to one another. As created by God, angelic beings have a superior ontological place in the universe. In his interpretation, Williams considers (and, I believe, would want to admit) the possibility that God could endow angelic beings (as currently created) with a lesser ontological status than they currently have, thereby raising human nature (as currently created) to a superior ontological status. God could certainly have established, de potentia absoluta, the created order in a way different from our current experience of it. In fact, in an alternate world, one can imagine beings ordered differently. But the interpretation here seems to go further than this. Here, a second move involves us in a reflection upon divine freedom in light of the human ability to consider what God has done and what God might have done. The claim seems to be not just that God could have chosen a different cosmic order, but that God could have chosen to place beings of a particular nature (such as we know them) in a different ontological order. Here, I think, the interpretation goes too far and involves God in self-contradiction.

In what sense might this interpretation involve a contradiction? First, the reference to "cold fire" resembles a discussion of a "square circle" in that, given the definition of fire, the attribution of "coldness" would involve a logical contradiction. Because the essence of fire (as we know it) is heat, were God to create fire such that it be cold, this new fire would cease to be fire in any ordinary, meaningful sense. So the expression "cold fire" could, I suppose, have meaning in some alternate world known to God, but it would have no meaning for the human intellect in this world.$^{51}$ But a second contradiction is also implied by this interpretation. This involves the divine will and its relationship to itself. If God has (already) established fire in the present world such that its essence is what it is, then for God to change that essence (de potentia absoluta) in the manner Williams suggests would be for the divine will to contradict itself. In other words, the divine will would effectively will the complete opposite of what it wills, namely, that essence " $x$ " not be essence "x." Scotus is very clear on the impossibility of divine self-contradiction. ${ }^{52}$ This means that, if Williams's interpretation of

51. Since hotness is an accidental form of fire, albeit coeval, if God wished to make fire cold, he need only "suspend his concurrence and induce the accidental form of coldness."

52. "God, therefore, insofar as he is able to act in accord with those right laws he set up previously, is said to act according to his ordained power, but insofar as he is able to do many things that are not in accord with, but go beyond these preestablished laws, God is said to act according to his absolute power. For God can do anything that is not self-contradictory or act in any way that does not include a contradiction (and there are many such ways he could act); and then he is said to be acting according to his absolute power. Hence, I say that many other things can be done orderly; and many things that do not include a contradiction other than 
this point is accurate, then either Scotus has committed a serious fallacy in his own discussion of divine freedom as it relates to essences (thereby undermining Williams's effort to make his overall position coherent), or Williams is interpreting the reference to "cold fire" improperly.

For a moment, however, let us assume that Williams's interpretation is correct and faithful to Scotus himself. Then, I think, if we are to entertain seriously the possibility that not only could God act in such a way, but that God would act in such a way, we must also take seriously what Scotus understands the nature of God to be and in which instances he might understand God to act in this way. The obvious case that comes to mind when "cold fire" is mentioned has to do with the experience recorded in the book of Daniel where the three young men were in the fiery furnace, yet not burned. How is such an event possible? Is such an event "unjust" to the requirements of the natural order? In suspending fire's ability to burn, has God changed its essence, thereby acting unjustly or inordinately?

One can easily see that such a case falls under the broader discussion of divine dispensation, and thus to the distinction of powers in God. In his treatment of dispensations recorded in scripture, Scotus follows the tradition in pointing out that de potentia absoluta, God can do anything short of a self-contradiction. ${ }^{53}$ And de potentia ordinata, God sustains the natural order established by the divine will. Thus, regarding the possibility of cold fire, Scotus could only consistently hold that (1) such a divine act could not be universalized, since that would undo a prior divine creative choice, and (2) as an isolated event, such an act would be out of love and, therefore, consistent with the divine essence. Because the physical order and natural law are established by God and because God always acts rationally and in harmony with the divine essence as love, then divine action, whether dispensing human agents or suspending natural causal relationships (preventing fire from burning), never contradicts rational, ordered loving.

This interpretation does not limit divine freedom, as Williams might protest. Rather, it establishes the superiority of divine freedom over the created order, including the law. It also affirms that, whatever God chooses to do, God never ceases to be God. This means that, from the perspective of Christian belief, God will never act in a way that does not manifest love.

Williams rightly wants to show how, for Scotus, God is debtor to no one but Himself. God's choices are not determined by anything outside

those that conform to present laws can occur in an ordained way when the rectitude of such law-according to which one acts rightly and orderly-lies in the power of the agent himself." (Ordinatio I, 44 as quoted in Wolter, Will and Morality, p. 257). What I think Williams would have us do is consider and understand God's freedom de potentia absoluta from within human concepts derived from the present order ( $d e$ potentia ordinata), a clear reversal of the Scotist viewpoint.

53. Where, for example, Abraham is commanded to sacrifice Isaac and the Hebrews are commanded to despoil the Egyptians. 
the divine nature, nor are they compelled to exist by any sort of "divine necessity." But this does not mean that these choices are devoid of reason, nor does it mean that when they do exist, they are not explainable in terms of the divine nature. Williams states, for example, that in the divine act of creation, God's decision to create the world was not the result of the moment when the "divine intellect pointed out that creation was a reasonable thing to do, and the divine will fell in line." ${ }^{54}$ This statement is technically correct, but not because the divine will acted alone. It is true because the divine intellect and will are one. The manner of presenting the point at issue obscures what is at stake for Scotus when he discusses freedom in God. Since the divine essence always informs divine activity, the creation of the world results from a free, self-determined act of divine love which itself expresses the essence of that love. God is always free to choose, but God cannot choose counter to the divine nature. This would involve a contradiction. Because God is perfect goodness, every act of God shows forth that goodness, not necessarily but freely. The only necessity in God is that He be God. God's behavior is therefore explainable in light of the divine essence as love, because God is who God is.

\section{The Scotist Discussion of Divine Justice, Therefore, Is Not Libertarian}

In his presentation of Scotist thought, Williams consistently separates the divine will from the divine intellect. He claims that this is necessary, both to defend divine freedom and the contingency of the created order. ${ }^{55} \mathrm{But}$ this move seems to lessen God's ability, insofar as such a separation results in God's creative act being an act of which God was himself unaware, at least at the time. God could only know creation "after the fact." Divine creative agency would not be action that involved either God's intention or self-consciousness.

In addition to the ontological discussion of divine freedom, Williams spends a good deal of time in "The Unmitigated Scotus" on the question of justice and how God's behavior toward creatures is not constrained by any sort of justice (in Ordinatio IV, 46). Justice is likened to an external standard against which God's actions are measured. Since God's actions are motivated by nothing (Claim 3), the divine will is not bound by justice.

In this discussion, Williams misreads Scotus's intent and overlooks the importance of divine simplicity in any discussion of God. The Franciscan's consideration of divine justice (in Ordinatio IV, 46) depends upon a basic distinction that appears early in the Ordinatio Prologue and throughout his

54. Williams, "Libertarian Foundations," pp. 213-14.

55. Williams, "The Unmitigated Scotus," p. 175. 
texts as a methodological principle for the consideration of divine freedom. The distinction involves divine activity understood ad intra (natural and therefore necessary) and ad extra (free and contingent). This distinction should not obscure, however, the commitment to divine simplicity. Scotus reduces both senses of the term justice to "what God owes himself." 56 The divine will expresses necessarily the divine essence, since God is one. Divine will-acts are harmonious with the nature of God, that is, with love. Scotus's basic insight about the divine will is that God always acts according to his own nature. In other words, divine simplicity requires that divine acts of will necessarily express the divine essence as love. The necessity here is not causal; it is metaphysical. This is the reason (or the explanation) for the way God acts. ${ }^{57}$

The identity of the divine will with the divine essence is central to Scotus's discussion of the nature of God's justice. ${ }^{58}$ Scotus opens the body of the question with a definition of justice taken from Anselm and Aristotle. It, too, reveals the ad intra/ad extra distinction. According to Anselm, justice is "rectitude of the will served for its own sake" (De Veritate, c. 12). Aristotle adds that justice "has to do with another" (Nicomachean Ethics, V). The entire development of the question and its solution depend on this key distinction between God's self-relationship and God's other-relationships. For Scotus, the solution is very simple: God always acts in harmony with himself. ${ }^{59}$ Nothing interferes with divine simplicity and identity. Hence there is no justice in

56. "Not by way of disparaging these distinctions, I reply with greater brevity to the question that in God there is but one justice both conceptually and in reality, although by stretching the meaning of "justice" one could say that in addition to the aforesaid justice [viz., what he owes to himself] there is some justice, or rather something just, about the way he deals with creatures." IV, 46, 1, taken from codices A [f.270rb] and M [f.236vb]; Vivès n. 7, 20:424. English from Allan B. Wolter, "Scotus's Eschatology-Some Reflections," in That Others May Know and Love: Essays in Honor of Zachary Hayes, OFM, ed. Cusato and Coughlin (St. Bonaventure, NY: Franciscan Institute, 1997), p. 311.

57. So, the following statement in "Reason, Morality, and Voluntarism" (pp. 9192) is misleading: "In short, no facts about human nature, divine nature, particular people, or particular situations constrain God's contingent and sovereign willing of the moral law." To be sure, nothing "constrains" the divine will, but this does not mean that God has no reasons to act. God's nature does not constrain, but rather expresses itself in every act of the divine will.

58. See Wolter, Will and Morality, pp. 238-55. In a commentary on the question of divine justice and mercy, Wolter writes: "God's justice towards creatures is a splendid example of a perfection that does not exist formally, but rather eminently in God as a consequence of that love God has for his own goodness." See "Scotus's Eschatology," p. 305, n. 3.

59. This is what Scotus means when he says, "And if you ask why the divine will is determined to one pair of contradictories rather than to the other, I must reply that 'it is characteristic of the untutored to look for causes and proof for everything.' ... There is no cause why the will willed, except that the will is the will, just as there is no cause why heat heats, except that heat is heat. There is no prior cause." (I D. 8, pars 2, n. 299 cited in Williams, "The Unmitigated Scotus," p. 173). Rather than 
God that directs the divine will because there is no justice in God which is not identical to the divine will. It does not mean that the divine will is capable of acting "independently" of justice ${ }^{60}$ God's will is just, that is, it is right in its own preservation of itself. ${ }^{61}$ God's will is the "first rule or norm." In other words, it is justice.

In the discussion of commutative justice, Scotus turns quickly to mercy, when he states that such justice is comparable to that of a generous or liberal master who rewards the servant in excess of what is deserved. Likewise, a master "may punish delinquent servants to a lesser degree than they merit."62 The sort of justice Scotus has in mind involves liberality and generosity. These he explains not in terms of merit or demerit, but in terms of God's goodness and of divine integrity. He concludes with the statement:

And such is the distinction between these two kinds of justice that God cannot operate against or beyond the first justice [viz., what is due to his goodness], but he can go beyond what the second requires, but not in all matters, for he cannot damn the just or the blessed.

In the body of this question, Scotus points out that there is in God only one justice, "both conceptually and in reality." ${ }^{\text {" }}$ There is something just about the way God deals with creatures. Justice in God is that which naturally inclines him to render to his own goodness what is its due. In other words, justice in God is Deus diligendus est. But since what inclines God to render to his own goodness what is due is, in fact, nothing other than the divine essence, one comes again to the conclusion that justice in God is none other than the divine essence.

This one act of the divine essence has many secondary objects to which the divine will is contingently related. Yet, in all these relationships, the divine will cannot but manifest divine essence. Another way of saying this is the

drawing the conclusion of divine simplicity, Williams goes on to interpret divine choice in terms of "Scotus's account of our choices." (ibid). One cannot reasonably hold that the divine will provides the basis for Scotus's discussion of human freedom and then interpret statements about God's will in terms of the human experience of willing.

60. This appears to be what is suggested in "The Unmitigated Scotus" (p. 171): "As we saw earlier, the divine justice makes no demands on God's conduct with respect to creatures."

61. "It is clear that God has justice in both senses: the first [ ad intra] because he has rectitude of will-indeed a will that cannot be gainsaid, because it is the first rule or norm, and is 'served for its own sake.' Not that 'served' here implies any submission or acceptance on the part of the one observing it, but rather it is 'served for its own sake' in the sense that it is always spontaneously preserved. It is clear he also has justice in the second sense [ad extra], because he is upright to others, and therefore, in all his actions towards others there is rectitude" (Wolter, Will and Morality, p. 241).

62. Wolter, Will and Morality, p. 241.

63. Wolter, Will and Morality, p. 245. 
following: God's nature is such that divine creativity is without limit. Among the various "creatibles," only some have been brought into actual existence. These exist not necessarily, but contingently, since there is nothing about their nature that would require them to exist. Thus, the justice according to which we consider God's self-love is distinct from that according to which we understand God's relationship to the created order. Both, however, manifest the divine essence and are therefore just. The measure of justice for any divine act is found in God, not in the created order.

The divine will is self-determining in regard to certain objects, bringing them into actual existence as created. Scotus states:

And by this very fact this act is modified by that first justice, because that act is in harmony with the will to which it is conformed as if the rectitude inclining it this way were the first justice itself. ${ }^{64}$

The act of the will, itself the expression of the divine essence, is an act of rectitude identical to the first justice of the divine self-relationship. In establishing the created order, then, God acted justly and with rectitude. Whatever belongs or is due to this order was established at the moment God brought it into being. ${ }^{65}$

\section{The Scotist Discussion of Divine Acceptatio Is Therefore Critical}

A better understanding of Scotus's discussion of divine freedom depends upon other texts where he presents the divine will. Williams focuses primarily on the texts that deal with the divine will as it relates to the moral law. The discussion of acceptatio, for example, is never seriously considered. And yet, this discussion is key to his whole concern, because here one finds the God of Scotus acting freely: that is, generously rewarding human actions far beyond anything they might deserve. In the absence of such obviously theological texts, one can easily misread Scotus's position on divine freedom. Consider, for example, a text of the Ordinatio Prologue, where Scotus makes the following statement:

But by natural reason one in this life is unable to know these three points. Proof that the first cannot be known. Beatitude is granted as the reward of merits which God accepts as worthy of such a reward.

64. Wolter, Will and Morality, p. 249.

65. The extended discussion in "The Unmitigated Scotus" (pp. 166-67) of the principle of dependency of all reality upon the divine will is not apposite. First, the text in question is taken from the theological discussion of acceptatio and merit. Williams unfortunately extends this to the ontological realm and argues that divine freedom is libertarian because the divine will could, at any moment, create any essence inferior to any other essence. 
In consequence, beatitude does not follow with natural necessity from any kind of acts we may be able to perform, but is something that is freely given by God, who accepts as meritorious certain acts directed towards Him. . . . This acceptance of what is only contingently related to it depends solely on the divine will. ${ }^{66}$

This text certainly appears to destabilize the moral order, making it impossible short of a divine command theory to know about moral law. What natural reason would require is a law similar to the Decalogue. ${ }^{67}$ This passage represents the theologians' objection to the philosophers' position and is consistent with both a more libertarian construal of divine freedom and with the need for a divine revelation.

Nonetheless, a fuller understanding of Scotus's position takes seriously the way in which the divine will (as revealed in scripture) is disposed toward contingent human acts or, in other words, what Scotus says about divine liberality and the order of merit. The way in which the divine will is disposed, as noted above, is necessarily in harmony with the divine essence. For the Christian, this refers to the essence revealed as love. ${ }^{68}$ Thus, it is important to note other passages where Scotus states, for example, in Ordinatio I, 17:

And so it is well said that God always rewards beyond worth, universally beyond certain worth which an act merits-since that such be worthy of merit, this is beyond nature and its intrinsic goodness, from gratuitous divine acceptance; and even more, beyond that other which normally would be accepting the act, whenever God rewards by pure liberality. ${ }^{69}$

Accordingly, and in light of the Ordinatio Prologue discussion, the significant data from revelation relate not to the Decalogue, but to the divine acts of generous initiative in the covenant with Abraham and Moses, renewed in the incarnation. In other words, revelation is not needed for the moral law, but to confirm human reflection on the nature of that being who is the highest good.

There is a second reason why Scotus's presentation of acceptatio is relevant to a better understanding of divine freedom. Such a presentation informs our understanding of other texts involving the divine will. This is

66. Ordinatio Prologue, n. 18 (I, 12-13). English translation from Wolter, "Duns Scotus on the Necessity of Revealed Knowledge," p. 246.

67. This is the sort of argument Williams presents in "How Scotus Separates."

68. See, for example, Lectura I, 17, n. 116 (XVII, 217): "Deus est dilectio per essentiam" as well as the statement in De Primo Principio: "Communicating the rays of your goodness most liberally, you are boundless good, to whom as the most lovable thing of all every single being in its own way comes back to you as its ultimate end" (The Treatise on God as First Principle, ed. Allan Wolter [Quincy, IL: Franciscan Herald Press, 1983], 4.84, 144).

69. Ordinatio I, 17, n. 149 (V, 210-11). 
especially relevant to the libertarian case. That case began in "The Unmitigated Scotus" with what Williams called "The Principle." This principle states that an act is good, not because of its nature, but because the divine will accepts it. It was the basis for Allan Wolter's seminal discussion of the native freedom of the will. ${ }^{70}$ It is found in a discussion of the order of merit. Williams himself notes that the principle has a theological context, but that it can be extended beyond that discussion. However, it is one thing to say a principle can be extended beyond a given context and another to take it completely out of that context. The principle of radical dependence on the divine will figures as premise for the ontological argument about created essences ("cold fire") discussed above. That argument concludes, by means of a libertarian explanation, with the affirmation that reason cannot know moral truth without some sort of revelation or immediate moral intuition.

Even if Williams were justified in his ontological construal of this principle, he cannot both dismiss other theological texts as irrelevant to our understanding of Scotus and claim that he has allowed him to speak for himself. If the original proposition ("The Principle") that serves as premise for an argument about divine freedom comes from a theological discussion of merit, then one cannot consistently exclude other textual presentations of the order of merit, on the basis that they are not philosophically relevant. ${ }^{71}$ If one begins with a premise taken from a theological discussion, then all theological texts become not only relevant but important.

The discussion of the order of divine acceptatio points to the fact that the God of Scotus is not only a loving, caring sustainer of all that is, but also a God who rewards far beyond what human actions deserve. ${ }^{72}$ God acts always and everywhere out of love because God is love. In rewarding acts beyond what they deserve, God acts consistently: it belongs to love to be generous. Therefore, God's acts of liberality are not "unjust" because they give more than is deserved. Rather, they are "just" relative to God's essence; they are generous because love is generous. It is in this way that Scotus can conclude that, in God, justice and mercy coincide. ${ }^{73}$ God acts freely ad extra; however, God never ceases to be God. The act of creation was a free, rational, and

70. Allan Wolter, "Native Freedom of the Will as a Key to the Ethics of Scotus," in The Philosophical Theology of John Duns Scotus, ed. Marilyn McCord Adams (Ithaca, NY: Cornell University Press, 1990), pp. 148-62.

71. In "Reason, Morality, and Voluntarism," Williams states: "The order of merit, however, is no concern of the moral philosopher as such, and I shall ignore it in the discussion that follows." (p. 80, n. 26). If the order of merit is unacceptable for the moral philosopher, then it is unacceptable as a starting point for the discussion of libertarian freedom in God.

72. In "The Unmitigated Scotus" (p. 170) for instance, divine generosity is separated from the question of justice. For Scotus, divine generosity is central to the divine nature and appears in every act of justice.

73. See IV, 46, q. 4 as well as Wolter, "Scotus's Eschatology," for the development of this argument. 
loving act because, in God, freedom, reason and love are identical. They define the divine essence revealed in Scripture.

This does not mean that creation was necessary. It does mean, however, that God had reason to create in the manner He did, just as any artist has reason to create as she does. It also means that God's actions are explainable in terms (and only in terms) of the divine essence. If one were to ask, "why did Picasso paint such a picture in such a way?" it would not be surprising to hear as a response "because he was Picasso and that is the way Picasso paints." In a similar manner, were one to ask, "why does any artist create anything at all?" a reasonable answer might be "because they are artists." This does not mean that artists have to create, but it means that when they create they express themselves in the work of art. Artists are recognizable in their works. One might call this the principle of artistic integrity. So too, it might be helpful here to speak of a principle of divine integrity. This principle means that everything God does is done freely and out of love, not because creation deserves it, but because that is what God's essence means. God creates nothing out of necessity. But when God chooses to create, God cannot not be God. God is love and God continually and freely extends generosity to creatures.

\section{Consequently, the Discussion of the Human Rational Will Does Not Support the Libertarian Claim}

Central to the libertarian claim is the way that freedom in the will is exercised independently of reason. Because Scotus claims that the will acts independently of the intellect or of the object as presented to it by the act of intellect, Williams concludes that there are no reasons to explain a free action on the part of God and, consequently, human reason has no natural access to the moral law, other than revelation or moral intuitions. He also concludes that, in a manner similar to divine freedom, human freedom admits of no reasons either. ${ }^{74}$ What this interpretation overlooks is precisely the way Scotus presents and defends the will as sole rational potency.

Throughout his articles, Williams identifies reason with the intellect and suggests that it is at odds with the will's freedom. In "The Libertarian Foundations," this appears as the conclusion of a long contrast with Aquinas where Williams states:

Where there are competing considerations in favor of incompatible courses of action, the conflict cannot be resolved by reason. It can be resolved only by an act of will by which I decide to regard certain considerations as having a claim on me. ${ }^{75}$

74. See the discussion of reason and reasons in "Libertarian Foundations" (pp. 213-14) and "Reason, Morality, and Voluntarism" (pp. 73-74).

75. Williams, "Libertarian Foundations," p. 213. 
This text can only mean that the act of the will, by which the deliberation is resolved, has nothing to do with reason or rationality. Clearly here, the act of the will is not an act of reason, for it is presented in contrast to and undetermined by reason. Further on, Williams continues the distinction as it applies to the divine will, with the passage cited earlier: "It was not as if the divine intellect pointed out that creation was the reasonable thing to do, and the divine will fell in line."76

These passages reveal a subtle but profoundly significant misreading of Scotus. They both fail to take into account that, for him, the will, not the intellect, is rational. Williams states frequently that Scotus rejected Aquinas's account of the will as an intellective appetite. This is true. However (and despite this fact), I am not convinced that he has fully grasped what it means to say the will alone is rational and that this very rationality constitutes its freedom.

In "Reason, Morality, and Voluntarism," the disjunction between the will and rationality is the centerpiece for the "pseudo-problem" that Williams claims to have solved. The passage cited above presented human reason as "powerless to figure out what God wills in respect to the moral law," because God has no reasons to act. ${ }^{77}$ For this reason, moral commands have to be revealed. The reasons God would consult are those presented by the divine intellect. Reason, then is synonymous with the intellect. My interpretation is confirmed in the statement where, according to Williams, there are "no reasons God consults in order to decide what to do." Thus, for Williams, rationality (whether divine or human) is not to be found in the will. He claims there are no reasons for the actions of the will. This must mean that he does not hold the will to be rational. For, if the will is rational, then reason constitutes it and not the intellect. But if this is indeed the case, then the notion of rationality endorsed by Scotus must not be that used by Williams, located in the intellect. Scotus's understanding of rationality is the moral rationality of the will, as capable of self-control and self-determination.

A final example, from "The Unmitigated Scotus," confirms my reading of Williams. He states the following:

One might be tempted to think that if what is morally good depends on what God wills, it obviously follows that the only way we can know what is morally good is to know what God wills. And does that not mean that reason is powerless to tell right from wrong? It would seem that we could know what morality requires only by consulting Scripture or being granted a special revelation. And yet here Scotus is talking about right reason as an essential ingredient in a morally good act. Either Scotus is being inconsistent, or I have been wrong in portraying him as a voluntarist. ${ }^{78}$

76. Williams, "Libertarian Foundations," pp. 213-14.

77. See n. 6 above.

78. Williams, “The Unmitigated Scotus," p. 180. 
The only way to make sense of this passage is to assume that the term reason here refers to the intellect. Knowledge then would be of the content of propositions about moral goodness found in some sort of revelation. So, the disjunction in the closing statement is a false disjunction. It should read: Either Scotus is being inconsistent, or he actually holds that the will (and not the intellect) is rational. If the will is truly rational, then Williams is only in error when he portrays him as the sort of libertarian voluntarist he does. Scotus is indeed a voluntarist, but one who holds that the self-determined will is rational.

When it comes to the discussion of human freedom, the affirmation of the rational will is central to a correct understanding of Scotus's position. As noted above in the discussion of voluntarism, the Franciscan identifies loving and not knowing as the highest activity of the human person and, therefore, as the perfection of rational nature. With a focus on loving as central to human rational perfection, he grounds the primacy of the will as sole rational potency in two distinct approaches, one theological and one philosophical. These approaches, though different, offer mutual support to one another as each concludes that the rationality of the will defines its freedom. This means that, for Scotus, the will is free only because it is rational. There is no true freedom in an irrational act. There is no freedom where reason is absent.

The first, philosophical perspective is provided by Aristotle's Metaphysics and the distinction of rational from irrational potencies. It is an argument quia or a posteriori, from the existence of multiple effects to the existence of a cause capable of such production. This cause must be rational in order to explain the data of experience. The second, Anselmian discussion, traces the rationality of the will from a propter quid or a priori analysis of the conditions internal to the will (its moral affections) necessary to account for the will's capacity to govern its own movement as well as that of all inferior powers of the soul. Together, both approaches conclude to the affirmation of the will's freedom precisely on the basis of its rationality.

Scotus's argument in his Subtle Questions on the Metaphysics, Book IX, 15, is straightforward. ${ }^{79}$ It begins with Aristotle's distinction between rational and irrational potencies. According to the Stagirite, rational potencies have contrary effects, while irrational potencies admit of only one effect. In the absence of impediment, at the moment an irrational potency acts it cannot act otherwise than it does. The rational potency, by contrast, may act otherwise than it does or not act at all. Central to Scotus's point here is that, on the basis of this definition, the will and not the intellect is the sole rational potency.

There is a only a twofold generic way an operation proper to a potency can be elicited. For either the potency of itself is determined to act, so

79. Opera Philosophica IV (St. Bonaventure, NY: Franciscan Institute, 1997), pp. 675-99. 
that so far as itself is concerned, it cannot fail to act when not impeded from without; or it is not of itself so determined, but can perform either this act or its opposite, or can either act or not act at all. A potency of the first sort is commonly called nature, whereas one of the second sort is called will. ${ }^{80}$

The act of knowing, like the act of vision, requires certain conditions necessary to it. The eye, for example, in the presence of sufficient conditions (light, the object, etc.) cannot fail to see what is before it. So, too, the unimpeded intellect cannot fail to know, nor, when it knows, can it stop itself from the act of knowing. Only the will can stop the intellect, just as the will can restrain itself (its power to "act or not act at all"). Thus, on this basis, the intellect is a natural, irrational potency while the will as selfdetermining is the sole rational potency. The will's rationality makes it free (indetermined) because no amount of sufficient conditions external to it determine its movement. ${ }^{81}$ The will's ability to restrain itself ("not act at all") means that it is a self-mover when it acts. This power over itself, its ability to control its own actions reveals that the will is the rational potency.

The intellect belongs to the category of natural potencies and is at the service of the will. Consequently, Scotus only attributes rationality to it when it works with the will. ${ }^{82}$ The Franciscan admits that this is a surprising conclusion and wonders why Aristotle calls the intellect the rational potency when, in fact, a more sustained reflection on his own categories (rational and irrational) reveals that it is the will. He concludes that since the intellect is better known to introspection and its acts are more common, the philosopher has fallen into the obvious trap of identifying it with the rationality. ${ }^{83}$

80. "Iste autem modem eliciendi operationem propriam non potest esse in genere nisi duplex. Aut enim potentia ex se est determinata ad agendum, ita quod, quantum est ex se, non potest non agere quando non impeditur ab extrinseco. Aut non est ex se determinata, sed potest agere hunc actum vel oppositum actum; agere etiam vel non agere. Prima potentia communiter dicitur natura, secunda dicitur voluntas" (Quaestiones in Metaphysicam, IX q. 15, 22 [Opera Philosophica IV] 680-81).

81. "Ad secundum, si arguitur de voluntate, dico quod illa potest in actum, nulla determinatione in ipsa praeintellecta actua, ita quod prima determinatio, et tempore et natura, est in positione actus. Et si tunc de ipsa accipitur "in nihil potest nisi prius determinata', falsum est" (n. 66, 696).

82. "Et hoc modo videtur Aristoteles loqui et ponere talem ordinem, quod primo requiritur notitia aliqualis oppositorum. Sed ista ex se est insufficiens ad aliquid causandum extra, quia, ut arguit in 4 cap., tunc faceret opposita. Hoc non videtur sequi nisi quia intellectus (etiam cognoscens opposita), quantum ad illud causalitatis quod habet respectu eorum fiendorum extra, es se determinatus est ad illus cuius est. Et ita non solum non est rationalis respectu actus proprii, sed nec completive rationalis respectu actus extrinseci in quo dirigit" (n. 38, 685).

83. "Sed contra: quare saltem ita frequenter vocat potentiam rationalem intellectum, et non sic voluntatem, licet innuat secundum praedicta? Potest dici quod actus intellectus praevius est communiter actui voluntatis, et nobis notior" (n. 53, 691-92). 
The term rationality, then, refers to the capacity for self-movement, for a power to act in a manner independent of external conditions and determinants. Specifically, this is seen where the will can be in the presence of conditions that would normally produce an act and still not act. This ability to resist external conditions reveals the will's self-control and, ultimately, its self-determination. Because the will is rational, it is undetermined by external conditions and only determined by itself. In this way, rationality for Scotus entails freedom and moral responsibility.

Clearly, the Aristotelian perspective grounds autonomy and moral responsibility. It makes moral actions imputable to the agent, but does not offer any basis upon which one action may be better or more morally good than another. Scotus himself admits that this is not a complete explanation of the human rational will. What he needs to complete this analysis is the background or scale of value against which moral choice can be measured. In other words, he needs to show why, even with such self-control, not every act imputable to the moral agent is a good act.

He finds this background in Anselm's discussion of the moral affections within the will in his De Casu Diaboli. For Scotus, as for Anselm, these affections do not refer to two separate wills in conflict with one another in the heart of the moral agent. Nor are they felt affections or emotions. Rather, they are two innate inclinations or metaphysical desires that together constitute the rationality of the moral agent. One inclination is deemed "natural" the other "free." The first, natural inclination is the affectio commodi or the desire for happiness. This desire is properly finalized by the bonum utile (or goods of use) and has as its moral intention the good or satisfaction of the agent as realized by the possession and use of external goods. I follow John Boler here and identify this affection as a natural inclination toward selfrealization within the human moral realm. ${ }^{84}$ The properly moral affection is the affectio iustitiae or affection for justice, finalized by bonum honestum or in $s e$, that is, those goods worthy of love for themselves alone and thus not related to any concern for self-preservation or self-actualization. This is the human capacity for disinterested love and friendship.

These affections are finalized by an objective order of goods external to the moral agent: goods of use and goods of value. Since, in Aristotelian, Stoic, and Augustinian traditions, goods of value were, by definition, superior to goods of use, choice of the higher good was always the better choice. Because the human will is drawn to both sorts of goods and, more importantly, is equipped to govern its own desire from within itself, moral choice can be measured by the interaction of the two affections. The affection for justice is the properly moral affection because it governs the affection for happiness and is disposed to act in accord with the dictates of right reason. When the affection for happiness (self-regard) is moderated by the affection for

84. John Boler, "Transcending the Natural: Duns Scotus on the Two Affections of the Will," American Catholic Philosophical Quarterly 57 (1993): 109-28. 
justice (awareness of intrinsic worth), the moral agent loves in a rational and orderly manner. Because the moral agent is rational, such ordered loving constitutes the fullest rational perfection.

In every true and morally good choice, both affections are satisfied. This means that right loving constitutes the fullest human satisfaction. It does not mean that personal happiness is disregarded as morally insignificant, or that the self should be overlooked in favor of morally right behavior. In fact, this is precisely what the philosophers depicted in the Ordinatio Prologue overlooked. They did not understand the way in which loving rightly (and not a life of contemplation) leads to the fullest experience of human happiness. Loving God above all things is both the most perfect act of which the human person is capable and is that act by which the person experiences true happiness. Thus, in loving God, the two affections of the will are integrated and united.

But it is not only in love for God that the two affections are integrated. They are also at one in the human desire to act in a perfect manner. Scotus clarifies this point as follows:

To want an act to be perfect so that by means of it one may better love some object for its own sake, is something that stems from the affection for justice, for whence I love something good in itself, thence I will something in itself. And thus the good could have wanted happiness so that, by having it, they could love the highest good more perfectly. ${ }^{85}$

"To want an act to be perfect" is identical with wanting to act perfectly. But when I want to act perfectly, I desire my own perfection as a moral agent. This is normally identified with the affection for happiness. But here, Scotus states that it stems from the affection for justice. This passage can be explained insofar as it reveals the harmony between the two affections. In other words, when I desire my own perfection in terms of right and ordered loving, then my affection for happiness coincides with the affection for justice. My moral willing is most perfect. My character defines my action. The coincidence of the natural and moral affections in the act of perfect loving reveals that, first, the moral goal is not necessarily the triumph of a higher over a lower will, but the development of a character capable of sustaining its own integrity in acts of ordered love. Second, this coincidence points to happiness as the natural foundation for moral living. Third, it shows how, in a perfect moral choice, the human will can imitate the divine. When God loves the two affections always coincide because God is the highest good. As noted earlier, in every divine choice, love for the highest good is identical with love for the divine essence. God's happiness, then, is ordered loving.

85. Ordinatio II, 6, 2, in Wolter, Will and Morality, p. 477. 
As in God, human moral rationality finds its source in the dynamic interaction of the two affections. ${ }^{86}$ Their interaction explains what Scotus means by self-control, the foundation for moral living. Scotus speaks of the affection for justice as checkrein on the affection for possession.

Therefore, this affection for justice, which is the first checkrein on the affection for the beneficial, inasmuch as we need not actually seek that towards which the latter affection inclines, nor must we seek it above all else (namely, to the extent to which we are inclined by this affection for the advantageous) - this affection for what is just, I say, is the liberty innate to the will, since it represents the first checkrein on this affection for the advantageous. ${ }^{87}$

As the moral inclination, the affection for justice is the disposition of the will to love in an ordered manner. It moderates the will's natural desire to pursue its own perfection, experienced as the satisfaction of all desire. This desire is disposed to follow the dictates of right reasoning. This text clearly points to the foundational capacity for rational self-control within the will as its innate liberty to restrain and moderate itself in its choices.

Scotus reprises Anselm's discussion to illustrate the importance of the two affections. In the original Anselmian discussion, one is asked to consider a being that possesses only the affection for happiness. ${ }^{88}$ Would this being be free not to love the good understood as satisfying all desire? Would this being necessarily love whatever appears as the higher or fuller good? Anselm concludes that the being would love to the degree that it understood the goodness of the object and, therefore, would choose what appeared to satisfy its desire to the fullest extent. Such a will could not refrain from willing that toward which it necessarily inclines.

While Anselm's text focused on the desire for the good, Scotus presents the single inclination as an intellectual one. In other words, the being with only one affection looks very much like the philosophers depicted in the Prologue, whose entire life is devoted to the activity of contemplation understood as the fullest satisfaction of the natural desire to know. The intellectual inclination would move the agent in a manner parallel to the way in which animals are moved by sensible inclinations. Despite the intellectual potential and high level of perfection that this agent could realize through his choices, the perfection would never be anything but natural, and in no sense moral.

Both Scotus and Anselm insist that the being with only one affection would be incapable of moral choice. While the agent in question would have the capacity to choose one object over another (A rather than $\mathrm{B}$ ), this

86. See Boler, “Transcending the Natural," p. 114.

87. Ordinatio II, 6, q. 2, in Wolter, Will and Morality, pp. 469-71.

88. De Casu Diaboli, chaps. 14-26. 
choice would depend not on the agent but on how the object appeared to the agent. A would be chosen if A represented more personal fulfillment to the agent, more satisfaction. B might be chosen because it represents an intrinsic good or value. In both cases, the reason for choice lies outside the agent. In the case of a moral choice, the reason must lie within the agent. Choices of the kind mentioned above would only be moral choices when the agent possesses another, more foundational, capacity for free choice. This would be the capacity for not-A, that is, restraint from A, rather than choice for $\mathrm{B}$. This rational capacity grounds the moral order in self-control. Without it, no moral choice is possible.

In his modification of Anselm's distinction, Scotus makes it clear that intellectual desire is not the same as rational choice, since the being with only one affection has intellectual desire but is not capable of the self-control required for rational, moral choice. His discussion works to safeguard the ability of the rational will to suspend choice or execution, to accept all the conditions necessary for action and still not act. This capacity for selfcontrol is the rational key to the will's freedom and foundation for the moral realm. The possibility for such self-restraint depends upon certain types of moral inclinations, namely the two Anselmian affections. Their interaction explains rational self-control as the liberty innate to the will. This liberty is expressed in concrete acts of choice where one can choose, reject (velle/nolle) or refrain (non velle) from choice. These acts of choice are framed within a world of created goods that belong either to the category of use (utile) or value (honestum).

If Scotus's position on the human will were libertarian in the way Williams claims, it would be important to find texts that deny the will's rationality or, at least, deny the existence of an objective ordering of values external to the moral agent. Only then would it be possible to affirm that the human will, in its exercise of freedom, has no reasons to do what it does, no way to explain its own choice. Scotus affirms both the existence of an objective order of value constituted by the divine will and, more importantly, the rational constitution of the human will. Like the divine will, the human finds its reasons within its own character, grounded on the natural disposition to act rationally (the affection for justice) and developed by means of acts of ordered love that are themselves the expression of inner integrity.

A final text confirms this. It is taken from III, Suppl. D. 33 where Scotus discusses virtue. Note that Williams's definition of voluntarism was not sufficient to allow for the integration of virtue into moral discussion. Therefore, this text would be excluded by that definition and not figure in a consideration of Scotus's brand of voluntarism. It is, however, essential to the point of human reason and rationality.

No virtue acts with absolutely no deliberation. For just as no one acts in a fully human way unless that person acts intelligently, so-as regards 
those things that pertain to the end-no one acts in a human fashion without understanding the reason for acting, and this understanding is what deliberation means. ${ }^{89}$

Since no one acts "in a human fashion without understanding the reason for acting," Scotus must hold that human action is ultimately explainable in terms of reason and reasons. To be sure, the free rational will is never necessitated by the results of deliberation. But this does not mean that, at a fundamental level, human choice admits of no explanation. The reason one chooses to act or not has to do with character and moral integrity. Since these are internal to the will, they do not diminish its freedom for self-determination.

\section{NATURAL REASON REQUIRES NEITHER SCRIPTURE NOR MORAL INTUITIONS}

We come, finally, to the fourth claim of Williams's interpretation. This states, on the basis of the definition of voluntarism (Claim 1) and the discussion of divine libertarian freedom (Claim 3), that human reason needs some sort of revelation or immediate epistemic moral intuition in order to reconcile natural reason with freedom. Scotus is, then, a divine command philosopher on two fronts: first, the moral order depends upon the divine will acting independently of the divine intellect and essence; second, natural reasoning is incapable of reaching judgments of truth about the moral good in a mediated manner. Either some sort of supernatural revelation is necessary (Scripture, and in particular the commands of the Decalogue ${ }^{90}$ ) or there is an epistemically immediate moral intuition about the contingent commands of moral law (the last seven commands of the Decalogue).$^{91}$ In no sense can natural reasoning about human nature or divine nature, for example,

89. In Wolter, Will and Morality, p. 345.

90. "Thus, whatever natural knowledge of the moral law remains among those who do not know or accept revelation is either the half-understood remnants of a tradition originally of divine origin but now much attenuated, or a brute knowledge that is at the mercy of moral and intellectual decay. Those who stand outside revelation will therefore find themselves with a sense that they ought to obey precepts for which they can give no reason, and with an inclination to obey precepts that make no appeal to the interests that usually motivate them. The obvious conclusion is that there is no secure knowledge of the moral law apart from revelation." "How Scotus Separates," pp. 441-42.

91. In "How Scotus Separates," this revelation involves the commands of the Decalogue. In "Reason, Morality, and Voluntarism," this relates only to moral intuitions, as a type of revelation to the human heart. In either case, however, human reason left to itself is unable to know why the moral good is good. Moral perfection is separate from questions of happiness or human fulfillment. 
conclude to any foundational moral truths. The moral law is the law because it results from the divine will.

Williams's conclusion to the need for revelation or to moral intuitionism would only be warranted if Claims 1 and 3 were acceptable as they are presented by him: that is, if the will (whether divine or human) were not rational, if the divine essence were not perfect love and if loving were not the perfection of the human person. Given these three aspects of Scotist thought, it is easy to see how the moral law is both reducible to ordered love and lies within the natural grasp of human reason as it meditates on the created order or the operations of its own acts of willing. Loving is that activity that belongs to the will by nature and is grounded in its own internal rational constitution. The first practical principle "Good is to be loved, evil avoided" appears in Scotus's texts as "God is to be loved." One can arrive through mediated reasoning to this version of the principle when one considers that, if good is to be loved, then the highest good is to be loved in the highest manner. If God is the highest good, then God is most worthy of love.

Williams suggests in "Reason, Morality, and Voluntarism" that, because the commands of the second table of the Decalogue are contingent and not necessary, knowledge of their moral truth cannot be grounded in knowledge of any logically prior truth or any metaphysical reflection on human nature. Because of this, human reason must have immediate moral intuitions about contingent moral demands. In other words, when, in a particular situation, I know that it is wrong to lie (the eighth commandment), this knowledge comes as the result of an immediate moral intuition. I just know it. I do not (nor can I) reason to this as a conclusion from prior truths of a metaphysical nature. I might also take the truth of the statement "do not lie" from Scripture. But in neither case can I reflect or deliberate on the basis of any proposition that begins with a notion of divine nature, human nature or reason. Any argument that purports to do this will be invalid. ${ }^{92}$

In the interest of space, I present here only one counterexample to refute this claim of moral intuitionism. It deals with natural reason and the understanding that truth should be told. It could be seen as a demonstration of the eighth commandment. It appears in Quodlibet 18:

Every judgment begins with something certain. Now the first judgment about the appropriateness cannot pre-suppose some knowledge

92. "Wolter's mistake is to suppose that Scotus ever offers an argument for a contingent moral proposition... The connection between Scotus's voluntarism and the view that we cannot know the contingent part of the moral law by argument is quite straightforward. Scotus argues that the contingent part of the moral law is freely determined by the divine will.... So God's willing in one way rather than another does not follow from any prior truths; the proposition 'God wills P' is, if it is contingent, not merely contingent but immediate. Consequently, we know in advance that any argument purporting to establish the truth of a contingent proposition will be invalid" (Williams, "Reason, Morality, and Voluntarism," pp. 86-87). 
determined by another intellect; otherwise it would not be first. Hence it presupposes something certain but judged by this intellect, namely: the nature of the agent and the power by which he acts together with the essential notion of the act. If these three notions are given, no other knowledge is needed to judge whether or not this particular act is suited to this agent and this faculty. ... Knowing what it means to attain knowledge, it would also be clear to him what it is not appropriate for his mind to reach. ${ }^{93}$

From this, Scotus concludes that lying is never morally admissible. It clearly belongs to a category of moral truth derived from reflection on human nature. Scotus states unequivocally here that such a moral truth is judged and demonstrated on the basis of three prior notions: the nature of the agent, the power by which the agent acts, and the act itself. While the third might be considered epistemically immediate, the first two are clearly based on metaphysical reflection. And, while it may be that the commands are not the necessary result of human nature, it is conceivable that the commands of the Decalogue and rational human nature mutually inform one another, since they both depend on divine creative activity, both rational and free. In this way, reflection on one sheds light on the other. There is then no need for moral intuitions. Natural reason can attain moral truth by means of mediated reasoning.

This does not remove the significance of the fact that the last seven commands of the Decalogue belong to natural law large loquendo. For Scotus, the foundation for moral living can be understood as both natural and, ultimately, supernatural. The foundation is natural insofar as right loving perfects human rationality and promotes the best understanding of human happiness. The human will is naturally constituted to love the highest good. Moral development is tied to self-control and moral responsibility. The natural order is an objective order of goods. This order measures human choice.

But moral truth is not only accessible to natural reasoning. It is also revealed in Scripture. Natural and supernatural causes coincide to reveal not just that lying is wrong, but that the best judgments of natural reason reveal the divine desire for right living. The harmony of natural reason with revelation appears clearly in the Prologue discussion with the case of the "honorable pagan." 94

The "honorable pagan" represents an unbaptized person who is saved precisely because he or she follows his conscience faithfully and does what

93. Quodlibet 18 in God and Creatures, pp. 402-3. Williams's analysis of the contingent commands is based upon Ordinatio 3, 38, and taken from the early and uncritical Wadding edition. His analysis of "cold fire" in "The Unmitigated Scotus" (pp. 164-67) also uses the Wadding text. It is striking how many of Williams's arguments are based, in a similar manner, on non critical texts. He appears to assume that these texts have just as much (if not more) validity than other, edited texts. He never justifies this preference.

94. Ordinatio Prologue nn. 54-56 (I, 32-35). 
is right, in the absence of any knowledge provided by revelation or anyone to teach him of such revelation. The case appears as an objection raised by the philosophers to the theological position that revelation is necessary. Because such a person would be saved, they claim, no divine revelation is needed.

Scotus's response to this objection confirms that he does not endorse the need for Scripture in order for one to know what is morally good. He affirms that natural knowledge is the basis for moral action and imputability. Even though salvation is customarily understood in the context of the sacramental system, such a person as the honorable pagan merits reward $d e$ congruo. The pagan's morally good act is congruent with what is revealed in the law, but does not depend upon knowledge of the law as revealed. The pagan's act is morally good, states Scotus, because it is "in accord with what his natural reason tells him is right." ${ }^{95}$ This illustrates clearly that Scotus does not understand moral goodness to be independent of natural moral reasoning. The pagan's morally good act is performed in conformity with his own right reasoning.

If Scotus held that supernatural revelation were required in order to know moral truth, he should have responded that such a pagan would not be saved at all, because he or she had no knowledge of the moral law as revealed and no way to follow divine commands as commands. If Williams's interpretation of moral intuitionism were faithful to Scotus, then one would expect to find some mention of this sort of intuition in the text itself. There is, however, no mention of a moral intuition in this text, or any other Scotist text that I am aware of. This example shows how, without benefit of either revelation or immediate moral intuition, the nonbeliever still maintains a rational relationship to himself and to his own conscience, in short, to his own character. He has no particular understanding of God or of divine commands.

Williams's Claim 4 to moral intuitionism finds no textual basis in Scotus. It is an addition to Scotist moral thought which serves to reconcile the notion of libertarian freedom (Claim 3) with the textual requirements of Scotus's insistence that reason is foundational to the moral order (Claim 2). When Claim 3 is shown to be a false depiction of Scotus's notion of freedom, then the need for Claim 4 disappears. The reconciliation of a divine command foundation with the requirements of rationality is easily effected when one recognizes all the implications of Scotus's affirmation of the rational will.

The fact that the moral order is, indeed, founded on the divine will has significance for the believer. Scotus is a divine command philosopher in this foundational sense. Additionally, this means that, for the believer, the commands of the Decalogue are an enhanced and precise description of what God is like and what God asks of us. What God wants is our rational

95. Ordinatio Prologue n. 54 (I, 32). 
perfection. ${ }^{96}$ In loving the neighbor out of love for God, the believer not only enhances the natural social order, but deepens her own relationship with God. The last seven commands of the Decalogue make perfect sense in light of divine love and show themselves to be especially suited to our nature as beings perfected by love.

\section{CONCLUDING REMARKS}

While I strongly agree that Scotus has long been overlooked in the history of philosophy and that the centrality of freedom is key to his view of ethics, I do not think that Williams's position for a libertarian Scotus can be sustained. It fails, first, to take into account the historical context of thirteenth-century Franciscan thought and the fuller definition of voluntarism, as Scotus himself understood it. In addition, in his discussion of divine freedom, Williams dismisses too quickly the important theological discussions of the divine will. The important question, where Scotus is concerned, is not how he presents freedom in isolated texts, but rather how his theological insights inform and direct his moral discussion. Full and complete understanding of Scotus's moral approach is a challenging endeavor because he never had time to bring together in one text all aspects of his vision. I hold that a more faithful presentation of this Franciscan must take seriously his insight about the importance of theology in any understanding of human excellence. Theological passages should play an integral part in any presentation or analysis of his thought. Because Williams's interpretation consciously excludes such an approach, it is unable to integrate the textual passages into the much larger Christian context of Scotist thought. It fails thereby to let Scotus speak for himself.

When Williams takes up the notion of libertarian freedom, he overlooks two important points. First, he sees no real distinction between divine and human freedoms, nor does his argument adequately integrate divine simplicity into his analysis of divine essence, intellect, and will. Second, he consciously focuses on what is chosen, rather than examine more carefully the act of the will as an act. This would involve a more careful analysis of the velle/non velle distinction, rather than the velle/nolle distinction. This deeper act, when seen with the context of synchronic alternatives, reveals how the will is within its own power, how the affection for justice governs both freely and rationally and how the act of the will is still undetermined by external forces. But, if one turns to the velle/non velle act, then one cannot ignore

96. So, the claim that God does not desire our rational perfection ("How Scotus Separates," p. 443) is not accurate. God does not desire our mere intellectual perfection. God does desire our rational perfection since for Scotus, as for Augustine and Anselm, rational perfection means right and ordered loving. 
what lies within the will. Here, issues of virtue, reason, and moral rationality ground the discussion of freedom. At this point, it is hard to see how a libertarian would be satisfied to claim Scotus as his own. If Scotus is a libertarian, then his brand of libertarianism is not radical, since he allows for the influence of character (as belonging to the will) on freedom.

Finally, Williams's interpretation suffers from the way he identifies reason with the intellect. This mistake affects his ability to deal with the problem he rightly seeks to solve: how Scotus can affirm both the value of freedom and the importance of reason for moral living. The problem is rendered less troublesome when the will is seen to be the sole rational potency, and when moral rationality grounds the exercise of human freedom.

Because he does not sufficiently integrate Scotus's historical context nor theological insights into his interpretation, Williams misreads Scotus's discussion of the divine will, by ignoring the importance of the divine essence and simplicity. Because he identifies reason with the intellect, his analysis of divine willing pits intellect against will and justice against freedom. This inability to consider the divine essence as one and as defined by rational love affects his conclusions. It is, therefore, the way his assumptions inform his conclusions that leads Williams to conclude too swiftly to the libertarian claim. Such a move is, I think, unwarranted. Given the central importance of the divine will for Scotus, any separation of his texts from his theological insights is a dangerous course of action. Given Williams's own stated desire to let Scotus speak for himself, this course of action is self-defeating.

Scotus is first a Christian and, as a result, a philosopher-theologian who affirms the superiority of love over knowledge. His views about divine liberality are radical, not because he is a libertarian (which I think he is not) but because he is a Franciscan. 